\title{
DESIGNING BUSINESS FORMS TO PURSUE SOCIAL GOALS
}

\author{
Ofer Eldar*
}

The long-standing debate about the purpose and role of business firms has recently regained momentum. Business firms face growing pressure to pursue social goals and benefit corporation statutes proliferate across many U.S. states. This trend is largely based on the idea that firms increase long-term shareholder value when they contribute (or appear to contribute) to society. Contrary to this trend, this Article argues that the pressing issue is whether policies to create social impact actually generate value for third-party beneficiaries-rather than for shareholders. Because it is difficult to measure social impact with precision, the design of legal forms for firms that pursue social missions should incorporate organizational structures that generate both the incentives and competence to pursue such missions effectively. Specifically, firms that have a commitment to transacting with different types of disadvantaged groups demonstrate these attributes and should thus serve as the basis for designing legal forms.

While firms with such a commitment may be created using a variety of control and contractual mechanisms, the related transaction costs tend to be very high. This Article develops a social enterprise legal form that draws on the legal regime for community development financial institutions (CDFIs) and European legal forms for work-integration social enterprises (WISEs). This form would certify to investors, consumers, and governments that designated firms have a commitment as social enterprises. By obviating the need for costly social impact measurement, this form would facilitate the provision of subsidydonations to social enterprises from multiple groups, particularly investors (through below-market investment) and consumers (via premiums over market prices). Thus, this social enterprise form would

* Duke University School of Law; Duke Innovation and Entrepreneurship Initiative. I thank Richard Brooks, Jamie Boyle, John Coyle, Elisabeth De Fontenay, Brian Galle, Henry Hansmann, Yair Listokin, Richard Schmalbeck, Steven Schwarcz, Michael Simkovic, Emily Strauss, Rory Van Loo, Andrew Verstein, and participants in seminars at Duke University School of Law and Boston University School of Law for helpful comments and suggestions. I am also grateful to Heather Cron, Zach Lankford, Renuka Medury, Kelsey Moore, Catherine Prater, and Hadar Tanne for excellent research assistance. Email: eldar@law.duke.edu. 
be to altruistic investors and consumers what the nonprofit form is to donors.

Moreover, the proposal could facilitate the flow of investments by foundations in social enterprises (known as program-related investments, "PRIs") because it would help foundations verify the social impact of their investees. In addition, by giving subsidyproviders greater assurance that social enterprises pursue social missions effectively, the proposed legal form could facilitate public markets for social enterprises.

INTRODUCTION 939

I. LEGAL HYBRID FORMS SHOULD SigNAL COMMITMENT TO

SUBSIDY-PROVIDERS.... 945

A. Legal Structures for Channeling Subsidies to Third-Party Beneficiaries. 946

B. Is There a Need for a Legal Form? Organizational Law as a

Certification Mechanism. 951

1. Obstacles to Private Ordering 952

a. Control and Contractual Mechanisms Are Costly.... 952

b. Adequate Certification Mechanisms Do Not Always

Emerge. 955

2. Foundations and Program-Related Investments ........ 958

II. Evaluating THE EXISTING LEGAL HYBRID FoRMS ................ 963

A. For-Profits with General Social Purpose: The Benefit Corporation... 964

B. Organizations with a Constraint on Distribution: The Community Interest Company..................................... 968

C. Social Enterprises That Transact with Their Beneficiaries:

The WISE Legal Form 973

III. Corporate Subsidy Programs as Public CERTIFICATION MECHANISMS 978

A. CDFIs as a Template for Legal Hybrid Forms 979

B. Design Flaws in Other Corporate Subsidies 985

C. Alternatives to Certification: Mandatory Requirements To Transact with Beneficiaries 988

IV. THE DESIGN OF A SOCIAL ENTERPRISE LEGAL FORM.............. 989

A. Identifying and Differentiating Among Beneficiaries ...... 990

$B$. The Scale of the Social Enterprise. 992 
C. Subsidy-Lock: Terminating the Social Enterprise

Certification 993

D. Fiduciary Duties

E. Public Markets for Social Enterprises

F. A Federal Agency for Certifying Social Enterprises

G. Mitigating Exploitation: Setting Minimum Terms Versus

Constraining Distribution.

H. Other Metrics for Social Impact .................................... 999

V. THE DESIGN OF GOVERNMENT SUBSIDIES ........................... 1000

CONCLUSION. 1004

\section{INTRODUCTION}

In recent years, there have been efforts to encourage firms to pursue social goals. In a striking statement to public corporations, Larry Fink, Blackrock's CEO, wrote: "Society is demanding that companies, both public and private, serve a social purpose. To prosper over time, every company must not only deliver financial performance, but also show how it makes a positive contribution to society." 1 The imperative that firms pursue social goals, however, is very vague. What range of permissible non-pecuniary goals should companies be encouraged to pursue? ${ }^{2}$ This question reflects a much re-hashed debate regarding the role and purpose of corporations. Many studies view this topic as a matter of corporate governance. That is, the key question is whether policies that seek to create social impact - often referred to as "CSR" (for corporate social responsibility) - maximize shareholder value in the long term. If the answer is yes, then it is a win-win situation for all because such policies are assumed to benefit society.

\footnotetext{
${ }^{1}$ Letter from Larry Fink, Chairman \& Chief Exec. Officer, Blackrock, to CEOs (2018), https://www.blackrock.com/corporate/investor-relations/2018-larry-fink-ceo-letter [https://perma.cc/7QRQ-9DG6]. For a similar statement by Martin Lipton, the renowned legal advisor for public corporations, see Martin Lipton et al., The New Paradigm: A Roadmap for an Implicit Corporate Governance Partnership Between Corporations and Investors To Achieve Sustainable Long-Term Investment and Growth, Harv. L. Sch. F. on Corp. Governance (Jan. 11, 2017), https://corpgov.law.harvard.edu/2017/01/11/corporate-governance-the-new-paradigm/ [https://perma.cc/B5AJ-EWNW].

${ }^{2}$ See generally Oliver Hart \& Luigi Zingales, Companies Should Maximize Shareholder Welfare Not Market Value, 2 J.L. Fin. \& Acct. 247 (2017) (arguing that company and asset managers should pursue policies consistent with the non-pecuniary preferences of their investors).
} 
This Article takes a different approach by arguing that the pressing question should be: Does the pursuit of social missions by for-profit organizations actually benefit the intended beneficiaries? While the literature is not conclusive, ${ }^{3}$ it is easy to see how a reputation for being socially responsible can help companies sell more products, attract investments, or even get more lenient treatment from regulators. However, just having a good reputation does not mean that CSR policies achieve their putative purpose of helping stakeholders and society at large. Without a mechanism for ensuring that CSR actually benefits the stakeholders, companies can easily use it as a means of "greenwashing." 4 Greenwashing may be particularly conducive to shareholder value because it promotes a strong reputation and higher sales without actually doing anything substantial for society. ${ }^{5}$ But — while false signals of doing good may increase shareholder value - those who support companies for their good deeds would presumably be disappointed were the truth to come to light.

The problem is that it is extremely difficult to verify companies' social impact. Existing measures of social impact tend to be vague, include metrics that are difficult to quantify, and even mix shareholder protection metrics with environmental or societal ones. ${ }^{6}$ But if measurement is rarely available, how do we know that firms are pursuing social goals effectively?

${ }^{3}$ Compare Ronald W. Masulis \& Syed Walid Reza, Agency Problems of Corporate Philanthropy, 28 Rev. Fin. Stud. 592, 619-21 (2015) (claiming that corporate donations advance CEO interests and reduce firm value), with Allen Ferrell, Hao Liang \& Luc Renneboog, Socially Responsible Firms, 122 J. Fin. Econ. 585, 585-91, 596-605 (2016) (arguing that well-governed firms are more engaged in CSR, and there is a positive association between CSR and shareholder value).

4 "Greenwashing occurs when a corporation increases its sales or boosts its brand image through environmental rhetoric or advertising, but in reality does not make good on these environmental claims." Miriam A. Cherry, The Law and Economics of Corporate Social Responsibility and Greenwashing, 14 U.C. Davis Bus. L.J. 281, 282 (2013).

5 This arguably explains why well-governed firms that are more accountable to their shareholders tend to engage in value-enhancing CSR. See generally Ferrell, Liang \& Renneboog, supra note 3. For a similar argument in the context of regulation, see Steven L. Schwarcz, Misalignment: Corporate Risk-Taking and Public Duty, 92 Notre Dame L. Rev. 1, 3-4 (2016) (arguing that regulation designed to align managers' and investors' interests does not necessarily help address negative externalities).

${ }^{6}$ This is most obviously manifested in the ESG metrics because they include both (i) governance metrics, which are supposed to increase accountability to shareholders and (ii) social and environmental metrics, which are supposed to measure firms' contributions to social and environmental objectives. 
The legal approach to addressing these questions has been to introduce legal hybrid forms - in particular, the benefit corporation. ${ }^{7}$ These forms are supposed to communicate to investors, consumers, workers, and society at large that firms' activities benefit society. To date, as many as thirty-six states, including Delaware, have adopted one or more such legal forms. ${ }^{8}$ However, existing legal forms fail to clarify the actual impact of companies' social goals. ${ }^{9}$ Just like CSR, these forms could portray a misleading picture of companies' social contributions. Many of the companies that adopt these legal forms have little or no discernible social impact. ${ }^{10}$ And companies that appear to be highly successful in pursuing social missions already had such impact before they adopted the legal forms. $^{11}$

Why have these forms seemingly failed to generate greater social impact? In this Article, I claim that they suffer from the same underlying problem as CSR policies. These forms are simply not structured in a way that makes companies more likely to pursue social goals effectively. Therefore, the legal forms cannot serve as useful signals to investors or consumers that the firms benefit society in the ways they purport to.

An effective legal form must meet two conditions. First, the form must give firms incentives to pursue social missions effectively. At the very least, the goal of maximizing shareholders' profits should not interfere with the firm's social mission. Ideally, the firm should have a financial

\footnotetext{
${ }^{7}$ See infra Part II.

${ }^{8}$ B Lab, State by State Status of Legislation, Benefit Corp., http://benefitcorp.net/policymakers/state-by-state-status? [https://perma.cc/X524-35UE] (last visited Mar. 18, 2020).

${ }^{9}$ See, e.g., John E. Tyler III, Evan Absher, Kathleen Garman \& Anthony Luppino, Purposes, Priorities and Accountability Under Social Business Structures: Resolving Ambiguities and Enhancing Adoption, 19 Advances Entrepreneurship Firm Emergence \& Growth 39, 39 (2017) (arguing that "social business models do not meaningfully prioritize or impose accountability to 'social good' over other purposes").

${ }^{10}$ See Ofer Eldar, The Role of Social Enterprise and Hybrid Organizations, 2017 Colum. Bus. L. Rev. 92, 99 (discussing Laureate University, a for-profit network of universities incorporated as a benefit corporation but that uses aggressive promotional tactics and has low graduation and loan repayment rates); see also Michael B. Dorff, James Hicks \& Steven Davidoff Solomon, The Future or Fancy? An Empirical Study of Public Benefit Corporations 46 (Eur. Corp. Governance Inst., Working Paper No. 495, 2020), https://papers.ssrn.com/sol3/papers.cfm?abstract_id=3433772 [https://perma.cc/D9R8-VZWC]. Dorff et al. list standard firms, such as Ripple Foods, as having incorporated as benefit corporations, even though these firms do not have any clear social impact other than producing goods (such as dairy-free milk) that appeal to certain consumers.

${ }^{11}$ Two such examples include the Greyston Bakery and Patagonia. See Eldar, supra note 10 , at 189 n.270.
} 
stake in the accomplishment of the social mission. Second, the firm should have the competence to pursue such missions. Competence is particularly important because social goals, such as unemployment or access to capital, tend to be complex. Accomplishing complex social goals requires the firm to tailor its social programs to the specific attributes and needs of the beneficiaries.

The issues of incentives and competence are very similar to standard issues in corporate governance. Broadly stated, the main goal of corporate governance policy is to ensure that managers have both (i) the incentives to maximize shareholder value and (ii) the competence to make decisions on behalf of the corporation. ${ }^{12}$ What complicates things when it comes to social responsibility is that a firm that purports to pursue CSR not only makes profits on behalf of the investors, but it also serves as a conduit for a subsidy or a donation. As I explain elsewhere, these subsidies or donations need not be direct transfers from the government or donors. In fact, they are usually latent in the sense that they reflect premium prices paid by consumers or below-market returns from investors. ${ }^{13}$

For policy makers, the main design issue is how to assure those who provide subsidy-donations that they will be used effectively. Thus, the principal goal of this Article is to develop a legal form with key structural elements that give managers the incentives and competence to accomplish this. This form can signal to stakeholders that firms professing to promote social impact actually do what they claim.

The policy I propose is modeled on the structural elements found in social enterprises that transact with their beneficiaries (e.g., as consumers or workers), which I have addressed in previous work. ${ }^{14}$ The transactional relationship with its beneficiaries gives the firm a stake in helping them develop, and also enables the firm to observe beneficiaries' abilities and needs. Thus, such firms have both the incentives and competence to serve certain social goals. The proposal builds on the regulatory regime for community development financial institutions (CDFIs), which certifies

\footnotetext{
${ }^{12}$ See Zohar Goshen \& Richard Squire, Principal Costs: A New Theory for Corporate Law and Governance, 117 Colum. L. Rev. 767, 784 (2017) (identifying conflict costs and competence costs as the two main sources of costs that corporate governance is designed to address).

${ }^{13}$ Eldar, supra note 10 , at 104-05.

${ }^{14}$ See id.; see also Ofer Eldar, The Organization of Social Enterprises: Transacting Versus Giving 10-15 (July 27, 2018) (unpublished paper), https://papers.ssrn.com/sol3/papers.cfm?abstract_id=3217663 [https://perma.cc/S36D-3LWP].
} 
financial institutions as firms that serve low-income populations, ${ }^{15}$ and combines this regime with certain elements found in benefit corporations. ${ }^{16}$

In essence, the proposal is to introduce a new social enterprise (SE) legal form. Firms organized under the SE legal form would be required to obtain a government certification as a "Social Enterprise" if they commit, in their charters, to transacting with one or more carefully defined classes of beneficiaries. These beneficiaries may include, among others, workers, borrowers, and consumers. Beneficiaries will be divided into different classes in accordance with certain criteria of need (e.g., level of income). To maintain the certification, firms must commit to having a minimum percentage of their business associated with beneficiary transactions. Whereas current benefit corporation laws permit companies to choose a third-party standard that measures their social purpose, ${ }^{17}$ my proposed reform would require companies to adhere to one federal standard defined by a single federal certifier.

The main goal of this proposed policy is to facilitate the flow of subsidized capital and income to social enterprises. This legal form is necessary to attract subsidies from dispersed subsidy-providers, such as investors and consumers. Currently, investors and consumers mainly rely on costly contractual and ownership mechanisms to ensure that relevant firms transact with their beneficiaries. Under the proposed system, investors and consumers would have notice that the firm transacts with beneficiaries before they purchase shares or products. In this respect, the proposed law would be to altruistic investors and consumers essentially what the nonprofit form is to donors. ${ }^{18}$ Thus, the proposal is likely to unlock much-needed capital to scale social enterprises and increase social impact.

\footnotetext{
15 The CDFI regime is currently limited to low-income borrowers, but it could be extended to a wider class of beneficiaries, and extended beyond the U.S.

${ }^{16}$ Specifically, as in benefit corporations, a qualified majority voting is required to change the mission of the firm. See infra text accompanying note 111.

${ }^{17}$ The MBCL provides criteria for third-party standards, but companies have discretion to select how their performance will be measured. See infra Part II.

18 The nonprofit form assures donors that the managers of donative organizations have limited incentives to expropriate the subsidy-donations; hence, they are more likely to distribute donations to the intended beneficiaries. Henry B. Hansmann, The Role of Nonprofit Enterprise, 89 Yale L.J. 835, 838-39 (1980). Similarly, the proposed legal form would assure investors and consumers that the firm has incentives to use subsidies effectively.
} 
The ability of the SE legal form to source subsidies from a wider range of subsidy-providers could serve two additional complementary objectives. First, it could help facilitate the process for allocating subsidized investments (known as program-related investments or "PRIs") from foundations. While most policy initiatives seek to attract institutional shareholder investment to channel capital for social goals, the best candidates for investing in social impact are foundations. The reason is that they have vast amounts of capital that they are supposed to employ to further philanthropic goals. ${ }^{19}$ Paradoxically, foundations often resist making PRIs in for-profit social enterprises because such investments could expose them to tax penalties if they cannot verify the social mission of their investees. Currently, such verification is cumbersome and subject to legal uncertainty. Thus, making certified firms eligible for PRIs would facilitate the process for allocating such investments.

Second, more ambitiously, the proposal has the potential to meet a long-awaited goal of social entrepreneurs: facilitating their access to capital markets. The inability of social enterprises to tap into capital markets substantially burdens their ability to grow and increase their social impact. Attempts to establish social exchanges for firms that combine profit and missions have largely been futile, primarily due to the difficulties of measuring social impact. A new legal form could help by providing adequate assurance to the investors who are expected to subsidize such impact.

One objection to this proposal might be that a legal hybrid form based solely on firms' transactional relationships with their beneficiaries is overly reductive or too narrow. Should a legal hybrid form not capture the universe of social missions, such as the protection of the environment, diversity, and human rights? These objectives are indeed laudable, but it does not follow that legal forms can adequately address them. In the absence of credible certification mechanisms and clear metrics of social impact, legal forms for organizations with broad social purposes are not likely to signal that these firms pursue social missions effectively. Furthermore, the class of organizations that transact with disadvantaged

19 See, e.g., Matt Onek, Philanthropic Pioneers: Foundations and the Rise of Impact Investing, Stan. Soc. Innovation Rev. (Jan. 17, 2017) https://ssir.org/articles/entry/philanthropic_pioneers_foundations_and_the_rise_of_impact_investing\# [https://perma.cc/MJ7A-52Q8]. 
persons is large and highly consequential. ${ }^{20}$ Concentrating on these firms could transform legal hybrid forms from a marginal phenomenon to a remarkable vehicle for promoting development.

This Article proceeds as follows: Part I describes how legal hybrid forms are supposed to serve as a commitment device to potential subsidy providers and explains why a new form is necessary to facilitate the formation of social enterprises. Part II critically evaluates the principal existing legal forms for companies with a social purpose and explains why they fail to serve as adequate commitment devices. Part III discusses the key elements of the CDFI regime and why other certification mechanisms do not work as well. Part IV proposes a design for a new legal form for social enterprises and discusses its principal elements in detail. Part V discusses the design of possible government subsidies for the proposed legal hybrid form.

\section{LEGAl Hybrid Forms SHOUld Signal COMMitMENT to Subsidy PROVIDERS}

Commercial firms that promote social goals ("hybrid organizations") are best viewed as business enterprises that channel subsidies to one or more types of third-party beneficiaries. ${ }^{21}$ The simplest example of a hybrid organization is a for-profit firm that donates a percentage of its profits for the benefit of a specific group, such as a homeless population. The subsidy generally flows from consumers who pay premium prices because the firm has a reputation for making such donations. These consumers are presumably willing to pay more because they want to support the firm's charitable cause. But how can the firm assure these altruistic consumers that it actually furthers its charitable mission?

Subsidy providers may worry because there is a risk that the managers of the organization will expropriate the subsidies instead of using them for the intended beneficiaries or that the subsidies will be distributed to beneficiaries in an ineffective way; for example, money might be wasted on fanciful projects with no tangible benefits. Therefore, the role of legal forms for these firms must be to create a commitment device that assures subsidy providers that their subsidies are used effectively for their

\footnotetext{
${ }^{20}$ For example, they range from microfinance institutions to firms that provide eyeglasses in developing countries.

${ }^{21}$ Eldar, supra note 10, at 104.
} 
intended purposes. Section I.A outlines three ways that firms channel subsidies, and Section I.B explains why a legal form is necessary.

\section{A. Legal Structures for Channeling Subsidies to Third-Party Beneficiaries}

There are essentially three types of legal structures for organizations that channel subsidies to third-party beneficiaries. The first type consists of organizations with a legal commitment to pursue general social purposes (for example, a charter provision that requires the firm to engage in CSR initiatives). The problem with these organizations is that they lack the incentives to use subsidies effectively.

First, CSR programs are a particularly useful marketing tool for boosting a firm's reputation and goodwill. Firms thus have incentives to exaggerate the scale and effectiveness of their social pursuits to consumers and investors. Consider an investment bank that runs a training program for small businesses in a low-income community. The bank does not typically invest in such businesses; it only transfers subsidies to them. Consequently, the bank is unlikely to examine the quality of its training, but will nonetheless announce it to gain good publicity. Likewise, firms have incentives to portray cost-cutting measures as pro-social policies that sacrifice shareholders' profits. For example, customers may be unable to evaluate whether a subsidy is necessary to induce firms to adopt environmental policies, such as recycling or energy efficiency measures. Such policies may be profit-maximizing on their own because they minimize costs. But, if altruistic consumers perceived them to be profitsacrificing, then they are more willing to pay premiums for firms' products. Thus, CSR policies may create value for shareholders without a corresponding value to third-party beneficiaries that would not accrue to them anyway. ${ }^{22}$

Second, when managers have wide discretion to pursue social goals, they often use this discretion to bolster their own reputations and entrench

22 See Andrew Price, Why Companies Make False Corporate Social Responsibility Promises, Fast Company (Feb. 21, 2012), https://www.fastcompany.com/1679334/whycompanies-make-false-corporate-social-responsibility-promises [https://perma.cc/6DTC$8 \mathrm{UYB}$ ] ("Companies in the developed world may respond to civil society and investors' pressure to take social responsibility more seriously by adopting CSR frameworks, but only to appease their critics and without any attention to actual changes in their practices."). 
themselves. ${ }^{23}$ Underperforming managers may block a takeover that will benefit shareholders and lead to their dismissal by claiming that they seek to protect local stakeholders. ${ }^{24}$ Managers may also use their discretion to shift value to charities that are affiliated with them ${ }^{25}$ or to influence politicians, ${ }^{26}$ without much regard to the charities' impact. Thus, CSR could constitute value-shifting from consumers and investors to managers themselves.

Third, in theory, social impact measurement and evaluations could give subsidy providers information as to whether their subsidies are used effectively. ${ }^{27}$ But such measurement is usually impractical. Consider again the example of business training offered by a bank. It may take years before information on its effectiveness is available, and it is difficult to attribute any outcomes to the training itself. There is no systematic way of measuring and reporting the positive externalities of CSR policies. While numerous social ratings, standards, and certifications have emerged in recent years, their development is still in a nascent stage, and they are often uninformative. ${ }^{28}$ This makes it easier for firms to use CSR to promote their reputations without delivering tangible social impact.

The second type includes organizations with constraints on distributing profits to those who control them. Constraining distributions is the traditional response to the concern that managers may misappropriate subsidies. This constraint on distribution is typically a total bar - as it is in nonprofits - but it may also be a cap on profit

${ }^{23}$ See Henry Hansmann \& Reinier Kraakman, The End of History for Corporate Law, 89 Geo. L.J. 439, 447-48 (2001); Michael C. Jensen, Value Maximization, Stakeholder Theory, and the Corporate Objective Function, 14.3 J. Applied Corp. Fin. 8, 14 (2001).

${ }^{24}$ Giovanni Cespa \& Giacinta Cestone, Corporate Social Responsibility and Managerial Entrenchment, 16 J. Econ. \& Mgmt. Strategy 741, 742 (2007).

${ }^{25}$ Masulis \& Reza, supra note 3, at 592 (finding that corporate giving is positively associated with CEO charity preferences).

${ }^{26}$ Marianne Bertrand, Matilde Bombardini, Raymond Fisman \& Francesco Trebbi, TaxExempt Lobbying: Corporate Philanthropy as a Tool for Political Influence 3 (Nat'l Bureau of Econ. Research, Working Paper No. 24451, 2018) (finding that grants to charitable organizations in a congressional district increase when its representative obtains seats on committees that are of policy relevance to the firm associated with the donation).

${ }^{27}$ Anup Malani \& Eric A. Posner, The Case for For-Profit Charities, 93 Va. L. Rev. 2017, 2036, 2057 (2007) (suggesting that an independent auditor could monitor the performance of a contract between the donor and for-profit firms to transfer value to the intended beneficiaries); Gwendolyn Reynolds et al., A Playbook for Designing Social Impact Measurement, Stan. Soc. Innovation Rev. (Dec. 21, 2018), https://ssir.org/articles/entry/a_playbook_for_designing_social_impact_measurement [https://perma.cc/PCN6-3WUK].

${ }^{28}$ Eldar, supra note 10 , at 187. 
distribution. The classic example is donative organizations (e.g., Oxfam), which are organizations that are funded by donations and distribute those donations to their beneficiaries. ${ }^{29}$ The non-distribution constraint prevents those who control the organization from expropriating the donations, thereby making it more likely that the firm will distribute them to the beneficiaries. ${ }^{30} \mathrm{~A}$ constraint on distributions can also be adopted by commercial firms that sell products or services. ${ }^{31}$ By mitigating the controllers' incentives to pursue profits, there is a higher likelihood that firms will (i) act fairly towards their stakeholders, including their consumers and employees, ${ }^{32}$ and/or (ii) contribute some of their revenues to the community. ${ }^{33}$

A constraint on distributions seems to work reasonably well when the organization is supposed to perform relatively simple social missions. A useful example is distribution of food aid in a natural crisis. In economic terms, the organization does not face information asymmetries with respect to the needs and abilities of the beneficiaries; all of them presumably need food. ${ }^{34}$ However, where a social mission is complex, non-distribution constraints will not ensure that subsidies are properly used. Consider, for example, an employment-skills training program for a disadvantaged population. Such a program requires detailed information on the trainees' capabilities and backgrounds, the potential job market, and the skills that would enable trainees to succeed in that market. This means that, even where managers pass subsidies along to the intended beneficiaries, they may nonetheless do so ineffectively. The main reason is that - due to information asymmetries - managers may be unable to observe trainees' abilities, motivations, and needs. ${ }^{35}$ Accordingly, they may teach skills that trainees already have, cannot learn, or for which there is no demand in the local labor market.

\footnotetext{
${ }^{29}$ Id. at 118 .

${ }^{30}$ Hansmann, supra note 18 , at 863 .

${ }^{31}$ Eldar, supra note 10 , at $117,158$.

${ }^{32}$ For example, by providing higher quality products or services to their consumers. In this context, the nonprofit organization does not serve as a conduit for a subsidy, and the economic role of the non-distribution constrain is slightly different. Specifically, when a consumer cannot evaluate the quality of a service (e.g., complex medical services), the firm may adopt the nonprofit form to signal to the consumer that it will not compromise the quality of the services to cut costs and increase profits. Hansmann, supra note 18, at 864 .

${ }^{33}$ For example, by donating to charity or adopting environmentally friendly policies.

${ }^{34}$ Eldar, supra note 10, at 131 .

35 Id. at $125-27$.
} 
Therefore, while managers may have incentives to pursue social goals, they may lack the competence to do so effectively when the mission is complex. The non-distribution constraint does not help firms assess their activities' impact or communicate this impact to subsidy providers. Accordingly, it cannot enable organizations to serve as effective conduits for subsidies directed towards more ambitious social goals.

The third type of firms, which I term "social enterprises," have a commitment to transacting with different classes of disadvantaged groups, such as borrowers, workers, or producers. ${ }^{36}$ This type comprises a wide array of firms, including work-integration social enterprises (WISEs) committed to employing people that suffer from systemic unemployment; microfinance institutions (MFIs) that make loans to borrowers in developing countries; social investment firms that invest in small businesses which are perceived as too risky for commercial investors; firms that sell fair trade products (fair trade social enterprises or "FTSEs"), such as coffee, fruit, or garments, which are sourced from small producers in developing countries; and firms that sell low-cost essential goods and services, such as eyeglasses or ambulance services, in developing countries.

As I argue elsewhere, because of their structure, social enterprises have both the incentives and competence to pursue complex social missions, such as increasing access to capital and improving employment opportunities. ${ }^{37}$ The viability of all of these firms depends on the beneficiaries performing their role in the transaction, whether by showing up to work every day, repaying a loan, or growing marketable produce. Social enterprises, therefore, have incentives to make sure that their beneficiaries receive the subsidies they need to perform effectively. This transactional relationship also enables social enterprises to gather information on the needs of their beneficiaries. For example, a WISE is well-positioned to know what training an employee might need, and an MFI can efficiently gather data on the repayment periods and interest rates at which a group of disadvantaged borrowers are most likely to repay their loans. Moreover, measuring social impact is less vital for social enterprises because their impact is demonstrated by the number of disadvantaged individuals they transact with (for example, the number of disadvantaged workers employed).

${ }^{36}$ Id. at $106-18$.

${ }^{37} \mathrm{Id}$. 
The legal commitment to transacting with a class of disadvantaged patrons is the key element that gives social enterprises both the incentives and competence to tailor subsidies to their beneficiaries' needs. Without some commitment device, there is a risk that those who control social enterprises will renege on the mission of the firm to promote the development of disadvantaged groups by simply transacting with individuals who do not need help to access commercial markets, and in this way expropriate the subsidies for personal gain. Some kind of commitment device is necessary to lock the subsidy into the organization, and ensure that it is used to benefit the intended third parties. ${ }^{38}$ Three main types of commitment devices have evolved through private ordering for this purpose ${ }^{39}$ :

(1) Control mechanism: A nonprofit, often a foundation, controls the organization. The nonprofit usually provides some subsidy to the organization, and it maintains control to make sure that the organization transacts with the intended beneficiaries. Alternatively, the firm may be organized as a member-owned cooperative, where members are either employees committed to the mission, or even the beneficiaries themselves.

(2) Contractual mechanism: A contract between the social enterprise and a nonprofit or a government agency requires the social enterprise to transact with disadvantaged groups. For example, the government may enter into an agreement with a firm whereby the firm commits to selling affordable products (e.g., bed nets) to low-income individuals, and the government promises to pay a subsidy to the firm.

(3) Certification: A nonprofit or a government agency certifies that the organization is committed to transacting with disadvantaged groups. An example is the Fair Trade certification. The Fair Labeling Organization (FLO), a nonprofit, certifies that the firm sources its products from small producers in developing countries. ${ }^{40}$ Certified firms are licensed to attach the Fair Trade mark to their products, in order to attract subsidies from consumers who are willing to pay a premium for such products.

\footnotetext{
${ }^{38}$ Id. at 116, 150-52; see also Dana Brakman Reiser \& Steven A. Dean, Hunting Stag with Fly Paper: A Hybrid Financial Instrument for Social Enterprise, 54 B.C. L. Rev. 1495, 1505 (2013) ("For-profit forms themselves provide no mechanism to protect a social enterprise's legacy - to lock in social mission and prevent investors from selling out.").

${ }^{39} \mathrm{I}$ focus here on for-profit social enterprises. For nonprofit social enterprises, the commitment device is the nonprofit form. Eldar, supra note 10, at 117-18.

${ }^{40}$ Id. at $111-13$.
} 
Social enterprises may also adopt constraints on distribution in order to demonstrate a commitment not to exploit their beneficiaries. Social enterprises often arise in circumstances where no other firms are willing to transact with disadvantaged groups, making the group vulnerable to monopolistic exploitation. A constraint on distribution may be useful where the regulatory framework for protecting the beneficiaries is weak. ${ }^{41}$ This suggests that nonprofit social enterprises may be likely to treat their beneficiaries more fairly than for-profit ones. Thus, a nonprofit MFI would be less likely to charge predatory prices; likewise, a nonprofit WISE may be less likely to pay egregiously low wages.

\section{B. Is There a Need for a Legal Form? Organizational Law as a Certification Mechanism}

The fact that social enterprises have developed commitment devices without enabling statutes raises the question of whether legal hybrid forms are necessary at all. Here, I argue that these commitment devices are generally too costly and cumbersome for dispersed subsidy providers, such as everyday investors and consumers. They may also lack legal validity or may simply not be available in the market. Moreover, I show that such obstacles discourage significant capital flows from large foundations. Thus, a legal form could help overcome existing obstacles to private ordering and facilitate the provision of subsidies to social enterprises. The nonprofit form provides a useful illustration of how a legal form can serve this role. The nonprofit legal form effectively certifies to donors that the firm is subject to the non-distribution constraint, and therefore their donations are unlikely to be expropriated. ${ }^{42}$ Without the nonprofit form, individual donors would need to enter into, monitor, and enforce complex contracts that place restrictions on distributions of income to owners. ${ }^{43}$ Alternatively, they might acquire a controlling stake in such organizations and control directly how much income is distributed to the owners. Most donors are unable to afford these costs. The nonprofit form mitigates these costs, thereby facilitating subsidy-donations from dispersed donors to donative organizations. It

\footnotetext{
${ }^{41}$ Ryan Bubb \& Alex Kaufman, Consumer Biases and Mutual Ownership, 105 J. Pub. Econ. 39, 48 (2013) (showing evidence that nonprofit banks are less likely to engage in predatory pricing tactics).

${ }^{42}$ It also certifies that the firm operates in a certain authorized field, such as health or education. 26 U.S.C. $\$$ 501(c)(3) (2018).

${ }^{43}$ Hansmann, supra note 18 , at 844 .
} 
signals to dispersed donors that their funds will be directed to the intended beneficiaries. A legal form for social enterprises could serve the same function for providers of subsidies to social enterprises.

\section{Obstacles to Private Ordering}

A legal form would be unnecessary if it was costless for firms and subsidy providers to use standard private ordering mechanisms, such as contracts. In theory, any investor or consumer could contract with or establish control over a firm to ensure that it adheres to its mission of transacting with a class of disadvantaged beneficiaries. However, these methods entail very high transaction costs. While third-party certifiers may emerge to verify the mission of firms that purport to be social enterprises, they are generally unsatisfactory. A new legal form could mitigate this problem by certifying to subsidy providers that a firm transacts with a class of disadvantaged beneficiaries. Like the nonprofit form, such a legal form would allow subsidy providers to avoid the high transaction costs of contracting with or controlling the firms in which they invest.

\section{a. Control and Contractual Mechanisms Are Costly}

While control and contractual devices may work well for investors who have a significant stake in a particular social enterprise, ${ }^{44}$ they are generally ineffective in reassuring a large segment of subsidy providers: dispersed investors or consumers who wish to contribute small amounts to social enterprises. Such subsidy providers have little competence or desire to examine the articles and bylaws of specific companies to make sure that they are committed to a social purpose. They may be even less equipped to establish the voting rights necessary to control the firm and ensure that it retains that purpose. Similarly, they lack the capacity to enter into and enforce contractual arrangements that require the commercial firms to perform a social purpose. ${ }^{45}$ If subsidy providers

\footnotetext{
${ }^{44}$ See Brian Galle, Social Enterprise: Who Needs It?, 54 B.C. L. Rev. 2025, 2037 (2013) ("If the [social] goals are readily defined, quantified, and measured, then both contract drafting and enforcement can be fairly cheap.").

${ }^{45}$ Many firms have trusting clients who are familiar with them, and who therefore provide subsidies regardless of commitment device. For example, many firms that sell fair trade products for which there is no Fair Trade mark are able to communicate and market their mission to trusting consumers. But with a growing number of social enterprises, consumers
} 
cannot (i) distinguish between firms that use subsidies effectively and those that do not, or (ii) bear the costs of assuring effective use of subsidies by contract or control, then it is likely that investors will simply direct fewer subsidies to social enterprises.

Consider an altruistic individual who wants to make a $\$ 1000$ donation towards improving employment opportunities in low-income communities. She is considering making a $\$ 10,000$ investment in a bakery that employs disadvantaged individuals. Suppose that an equivalent investment in a commercial bakery would yield a twenty percent return, whereas an investment in a bakery that employs the poor yields a ten percent return. Thus, the subsidy-donation is essentially $\$ 1000$. However, she is concerned that the other owners of the bakery might not be sufficiently committed to maintaining the mission of the firm, or that they may sell their shares to other investors who desert the mission. Like most individuals, she is unable to spend much time or money seeking legal advice or obtaining contractual commitments from the other investors. Therefore, she decides to donate $\$ 1000$ to a donative organization and to invest her $\$ 10,000$ in a commercial bakery —an investment that yields a gain of $\$ 2000$. For the social enterprise, the loss is $\$ 10,000$ in muchneeded capital.

The costs of creating commitment devices are particularly large for public investors who have no realistic way of coordinating with otherincluding future-investors in the firm. An investor who wants to support a social mission will be reluctant to pay a subsidy (e.g., by overpaying for the company's shares) without credible assurance that the firm will not distribute it to all the shareholders in the future. Public firms face substantial pressure from investors, such as hedge funds, who may acquire shares in dual-purpose companies and then require managers to pursue profits at the expense of social missions. ${ }^{46}$ For this reason, firms that are dedicated to the pursuit of social missions are typically closely held firms and have not been particularly successful in tapping public markets. ${ }^{47}$

will have difficulty distinguishing among them, and for-profit firms may thereby manipulate their social image to attract undeserved subsidies.

${ }^{46}$ Brett H. McDonnell, Benefit Corporations and Public Markets: First Experiments and Next Steps, 40 Seattle U. L. Rev. 717, 723-24 (2017). For some largely failed attempts to create "social" stock exchanges for firms with dual profit and social missions, see Sarah Dadush, Regulating Social Finance: Can Social Stock Exchanges Meet the Challenge?, 37 U. Pa. J. Int'l L. 139, 140 (2015).

${ }^{47}$ McDonnell, supra note 46, at 717-18. 
One might argue that most investors in social enterprises are not retail investors with limited means, but rather large, savvy institutions who are able to bear the costs of control and contractual mechanisms. The industry of environment, social, and governance (ESG) or socially responsible investing (SRI) is growing and is estimated at trillions of dollars in assets under management. ${ }^{48}$ However, it is unclear whether such institutions are conduits for subsidies, as many of them at least in principle seek market returns.$^{49}$ Others claim to pursue social impact at the expense of profits, ${ }^{50}$ but it is unclear whether they actually do. These funds are similar to forprofits with general social purposes which are difficult to measure; ${ }^{51}$ therefore, there is a concern that they may simply claim to pursue social impact to increase their fund flows. ${ }^{52}$ In fact, these funds seem to have no greater impact than conventional funds when it comes to complex social missions, such as community development. ${ }^{53}$

Finally, even if subsidy providers could bear the costs of contractual or control mechanisms, it is not clear that they are legally valid when the

48 As of July 2018, it was estimated to include more than $\$ 20$ trillion in assets under management. Georg Kell, The Remarkable Rise of ESG, Forbes (July 11, 2018), https://www.forbes.com/sites/georgkell/2018/07/11/the-remarkable-rise-of-esg/\#269ac0a16951 [https://perma.cc/WU26-AJS7].

49 Nick O'Donohoe et al., J.P. Morgan Glob. Res. \& Rockefeller Found., Impact Investments: An Emerging Asset Class 5-6, 30-38 (2010), https://www.jpmorganchase.com/corporate/socialfinance/document/impact_investments_nov2010.pdf [https://perma.cc/B586-7XHN]; Paul Brest, Ronald J. Gilson \& Mark A. Wolfson, How Investors Can (And Can't) Create Social Value 7 (Eur. Corp. Governance Inst., Working Paper No. 394, 2018), https://ecgi.global/sites/default/files/working_papers/documents/finalbrestgilsonwolfson.pdf [perma.cc/QM24-CLA6].

${ }^{50}$ For example, Barber et al. find that impact funds earn about four percent lower IRRs compared to traditional VC funds. Brad M. Barber, Adair Morse \& Ayako Yasuda, Impact Investing 3, 10-11 (Dec. 13, 2019) (unpublished paper), https://ssrn.com/abstract=2705556 [https://perma.cc/3C7R-U5EK].

${ }^{51}$ Gezcy et al. claim that impact funds use contracts with their investors and investees to operationalize impact. However, they neither present clear examples of the type of contracts that such impact funds use nor explain how these contracts can be effectively monitored. Christopher Geczy, Jessica S. Jeffers, David K. Musto \& Anne M. Tucker, Contracts with (Social) Benefits: The Implementation of Impact Investing 4 (Dec. 9, 2019) (unpublished paper), https://ssrn.com/abstract=3159731 [https://perma.cc/FX63-9TWX].

52 There is, in fact, evidence that flows to SRI funds exhibit greater growth than flows to conventional funds. Jedrzej Bialkowski \& Laura T. Starks, SRI Funds: Investor Demand, Exogenous Shocks and ESG Profiles (Dep't of Econ. \& Fin., Univ. of Canterbury, Working Paper No. 11/2016, 2016), http://www.econ.canterbury.ac.nz/RePEc/cbt/econwp/1611.pdf [https://perma.cc/NUB4-MYRX].

${ }^{53}$ Id. at 44-45 (finding that impact funds show no material impact as compared to a matched sample of conventional funds with respect to community, diversity, and the environment, but performed better on the governance and product scores, and negative screening). 
purpose of the firm is expressly expected to derogate from firms' profits. In a recent Delaware case, eBay Domestic Holdings, Inc. v. Newmark, ${ }^{54}$ the Chancery Court held that it could not "accept as valid ... a corporate policy that specifically, clearly, and admittedly seeks not to maximize the economic value of a for-profit Delaware corporation for the benefit of its stockholders." 55 The policy at issue was that of craigslist, whose two majority shareholders envisioned a corporate culture that served the community as a whole, rather than maximizing profits. ${ }^{56}$ The court rescinded a poison pill created to prevent eBay, a twenty-eight percent shareholder who did not share that vision, from acquiring more shares. ${ }^{57}$ Proponents of legal hybrid forms cite this case for the proposition that it is not possible to create hybrid organizations in Delaware. ${ }^{58}$ While it is likely that such a purpose would have been found valid had craigslist provided sufficient notice of its purpose to eBay before it acquired its shares (for example, through a charter provision), the case seems to create legal uncertainty for creating hybrid firms through control and contractual devices. A legal form could reduce this uncertainty.

\section{b. Adequate Certification Mechanisms Do Not Always Emerge}

Third-party certification is an alternative to control and contractual mechanisms. A certification means that a third party confirmed that certain criteria relating to an achievement or a process have been met. The advantage of such a system is that it can efficiently signal to dispersed subsidy providers that the firm deserves a subsidy. A well-known form of certification is Fair Trade, ${ }^{59}$ which is widely used by many large companies, including Starbucks, Nestlé, and others. ${ }^{60}$ This certification is designed to attract subsidies by assuring consumers that the relevant

\footnotetext{
${ }^{54} 16$ A.3d 1 (Del. Ch. 2010).

55 Id. at 34 .

${ }^{56}$ Id. at 8 .

${ }^{57}$ Id. at 48 .

58 The eBay case reflects the conventional view, dating back to Dodge v. Ford Motor Co., that the directors' duty is to maximize shareholders' profits. 170 N.W. 668, 684 (Mich. 1919); Jay Coen Gilbert, What eBay's Court Fight with Craigslist Reveals, Forbes (Sept. 21, 2010), https://www.forbes.com/sites/csr/2010/09/21/what-ebays-court-fight-with-craigslist-reveals/\#31e9416d2dd8 [https://perma.cc/BVC5-H4ST] (warning business owners not to incorporate their businesses in Delaware if they wish to maintain the social mission of their company).

${ }^{59}$ See supra note 45.

${ }^{60}$ Sushil Mohan, Fair Trade and Corporate Social Responsibility, 29 Econ. Aff. 22, 26 (2009)
} 
product was produced by disadvantaged farmers. ${ }^{61}$ Indeed, empirical studies show that the Fair Trade label has a substantial positive effect on sales. ${ }^{62}$

Fair Trade's popularity may suggest that a legal form is not necessary, or that private certification is sufficient. However, there is no assurance that appropriate forms of certification will evolve without government intervention. ${ }^{63}$ Many products are not yet covered by certifications; therefore, many low-income farmers cannot benefit from them. More conspicuously, there are no effective private certification mechanisms for firms that transact with disadvantaged workers, borrowers, and consumers.

Even where private certifiers exist, they often suffer from several deficiencies. First, the certification might apply only to products as opposed to the firm as a whole (as it does for Fair Trade). Product certification is not particularly useful for altruistic shareholders because a given firm may only sell a small quantity of Fair Trade products or abandon those products after altruistic investments are made.

Second, many private certifications have emerged to certify social impact, and each uses different criteria. ${ }^{64}$ Multiple certifications may lead to confusion among consumers, who may be unable to recognize or distinguish among them.

Third, many private certification mechanisms are overly ambitious in trying to evaluate impact based on numerous social, environmental, and governance criteria. It is not clear if the criteria for certification are designed to measure profit-maximizing policies (which do not require a subsidy) or profit-sacrificing policies (which require a subsidy). Many certifications include potentially irrelevant factors - such as governance scores and measures of stakeholders' participation - and the evaluation of companies is based on subjective discretion, rather than easily measurable

${ }^{61}$ Eldar, supra note 10, at 115-16, 152-53; Charles F. Mason, Certification of Socially Responsible Behavior: Eco-Labels and Fair-Trade Coffee, 7 J. Agric. \& Food Indus. Org. 1, 1 (2009).

62 Jens Hainmueller et al., Consumer Demand for Fair Trade: Evidence from a Multistore Field Experiment, 97 Rev. Econ. \& Stat. 242, 242 (2015).

${ }^{63}$ For discussion of potential reasons for the lack of adequate certification mechanisms, see Brian Galle, Self-Regulation of Social Enterprise, in The Cambridge Handbook of Social Enterprise Law 26, 31 (Benjamin Means \& Joseph W. Yockey eds., 2018); see also Jonathan M. Barnett, The Certification Paradox, in The Cambridge Handbook of Technical Standardization Law: Further Intersections of Public and Private Law 252, 257 (Jorge L. Contreras ed., 2019) (discussing the imperfections of private certification mechanisms).

${ }^{64}$ Eldar, supra note 10 , at $164-66$. 
criteria ${ }^{65}$ In fact, even the Fair Trade standards increasingly incorporate various environmental standards, such as organic production, biodiversity, and genetically modified crops. ${ }^{66}$ The merit of these requirements is not only far from settled, but it may also overburden lowincome farmers who may have difficulty paying for the certification. ${ }^{67}$

Fourth, there is a concern that certifications fail to properly define the class of disadvantaged beneficiaries. Certification may be over-inclusive and encompass people who are not truly disadvantaged, such that there is no need to provide a subsidy to the firm to induce it to transact with them. Where subsidy providers rely on such a certification, the firm may essentially expropriate subsidies it receives from consumers and investors who believe the firm is transacting with disadvantaged groups. There is, in fact, some evidence that the Fair Trade standards neglect poorer farmers yet cover farmers who may already be able to export their products to large corporations in developed countries. ${ }^{68} \mathrm{~A}$ proper certification system should identify a class of beneficiaries that is truly unable to transact with commercial firms because of market failures or insufficient abilities; otherwise, the certification would effectively mislead potential subsidy providers.

Fifth, there is a growing need for greater differentiation among social enterprises. Whereas many commercial firms that use the Fair Trade mark tend to focus on relatively capable farmers, other FTSEs focus on farmers who need more training and assistance in order to transact with commercial firms. ${ }^{69}$ These firms have no efficient way of communicating to their consumers that they transact with farmers with lower capabilities; rather, they must diligently educate their consumers on the background of their farmers. But most consumers have limited attention spans and may not trust the companies' claims. Accordingly, an economic means of

\footnotetext{
${ }^{65} \mathrm{Id}$. at 166.

${ }^{66}$ See Fair Trade USA, Agricultural Production Standards (APS) at a Glance 1, 9 (2017), https://www.fairtradecertified.org/sites/default/files/filemanager/documents/APS/FTUSA_G UI_APSOverviewWebLong_EN_1.0.0.pdf [https://perma.cc/P8F4-APFF].

${ }^{67}$ Paulette L. Stenzel, The Pursuit of Equilibrium as the Eagle Meets the Condor: Supporting Sustainable Development Through Fair Trade, 49 Am. Bus. L.J. 557, 637 (2012).

${ }^{68}$ Id. ("Fair Trade certification is prohibitively expensive for many individual producers and small groups of producers.").

${ }^{69}$ See, e.g., Who We Are, Fairtrasa, http://www.fairtrasa.com/we [https://perma.cc/B57CFLD8] (last visited Mar. 4, 2020) (stating that their goal is to assist smallholder farmers become sustainable ecologically and economically, for example through "help[ing] smallholders become certified organic agro-entrepreneurs who can produce for global markets, and after a period of transition, succeed without external support").
} 
communicating the class and abilities of beneficiaries and the extent of the subsidies they need is required.

A solution to these deficiencies could be the creation of a new legal form. This legal form would serve as a public certification mechanism. If based on proper criteria, a social enterprise legal form could serve as a single, credible signal to widely dispersed investors and consumers that a firm is not only unlikely to expropriate subsidies, but also is likely to use them effectively.

\section{Foundations and Program-Related Investments}

Although much of the literature on corporate social responsibility has focused on ESG investing, a more promising source of capital for social missions is investment from foundations. In order for foundations to make investments in hybrid organizations, the investments must qualify as program-related investments (PRIs). ${ }^{70}$ PRIs constitute subsidies from both foundations, as they typically involve below-market returns, and the government, because - unlike other investments - they are exempt from federal tax. However, PRI capital is largely unavailable for investment in hybrid organizations. The problem is that, like dispersed investors, foundations face uncertainty when providing subsidies to hybrid organizations without a certification mechanism. ${ }^{71}$ Unlike dispersed investors, the uncertainty stems largely from federal rules regarding PRIs.

Facially, PRIs seem advantageous for foundations. PRIs appear preferable to other forms of grants because they do not involve money transfers; rather, the foundations can recover their investments. There are several benefits to PRIs. First, PRIs count towards foundations' mandatory distribution requirements. ${ }^{72}$ Foundations must annually satisfy statutorily imposed minimums for expenditures made in furtherance of their charitable purposes which generally equal at least five percent of

\footnotetext{
${ }^{70}$ Otherwise, such investments which carry higher risk and lower return could be legally viewed as jeopardizing the foundation's financial ability to carry out its exempt purpose. Treas. Reg. § 53.4944-1(a)(2)(ii) (1973). If PRIs are treated as jeopardizing investments, they would be subject to a ten percent tax. 26 U.S.C. § 4944(a)(1) (2018).

${ }^{71}$ See Lloyd Hitoshi Mayer \& Joseph R. Ganahl, Taxing Social Enterprise, 66 Stan. L. Rev. 387, 423 (2014) (opposing tax benefits for hybrid organizations because "mechanisms, such as the hybrid enabling statutes, are insufficient to ensure that public benefit is indeed provided").

72 Treas. Reg. § 53.4942(a)-3(a)(2) (2015).
} 
their assets. ${ }^{73}$ Undistributed income is subject to a thirty percent tax. ${ }^{74}$ Amounts paid as PRIs qualify towards satisfying that minimum, thereby reducing the hefty tax liability. Critically, PRIs do not count as "private inurement"75 (creating benefits for insiders) or "private benefit" (benefits for outsiders other than those it is intended to aid), both of which can cost a foundation its tax-exempt status. ${ }^{76}$

Despite the advantages associated with PRIs, few foundations make them in practice. During the past two decades, less than one percent of U.S. foundations made PRIs each year. ${ }^{77}$ While the dollar amount of PRIs increased between 1990 and 2010, PRIs as a percentage of qualifying distributions have remained remarkably low and stable - hovering around one percent. ${ }^{78}$ As shown in Table 1, PRIs composed only a small percentage of qualifying distributions for the ten largest foundations from 2011 to 2015. Notably, three of these foundations made no PRIs at all during this period, and two more made only negligible amounts. Accordingly, few social enterprises are able to tap into the funds of foundations via PRIs.

7326 U.S.C. $\$ 4942(\mathrm{e})(1)(2018)$

${ }^{74}$ Id. $\S 4942$ (a). A jeopardizing investment may also trigger substantial excise taxes for the manager that made it. Treas. Reg. § 53.4944-1(b) (1973).

75 Daniel S. Kleinberger, A Myth Deconstructed: "The Emperor's New Clothes" on the Low-Profit Limited Liability Company, 35 Del. J. Corp. L. 879, 890-91 (2010).

${ }^{76}$ See Wendy L. Parker Rehab. Found., Inc. v. Comm'r, 52 T.C.M. (CCH) 51, 52-53 n.2 (1986) ("The prohibition against private inurement, in contrast, is complete, and the amount and extent of such inurement is not determinative." (citing Church of the Transfiguring Spirit, Inc. v. Comm'r, 76 T.C. 1, 5 (1981))); Mayer \& Ganahl, supra note 71, at 407.

${ }^{77}$ Una Osili et al., Leveraging the Power of Foundations: An Analysis of Program-Related Investing, Ind. U. Lilly Fam. Sch. of Philanthropy 2 (2013), https://community-wealth.org/content/leveraging-power-foundations-analysis-program-related-investing [https://perma.cc/D2ZM-F36A].

${ }^{78}$ Id. at 12 figs. 1 \& 2, 39 fig.2. "Yet, while many foundations have explored opportunities to leverage PRIs/MRIs to further their missions, the level of such outlays is surprisingly small, comprising less than $2 \%$ of private foundation endowments." Richard Henriques et al., Program-Related Investments 1 (2016), https://www.impact.upenn.edu/wp-content/uploads/2016/04/160415PRIFINALAH-print.pdf/ [https://perma.cc/RCC4-Q8PF]. "According to the IRS data, the share of PRI dollars in qualifying distributions by all foundations remained around 1\% each year over the past two decades." Heng Qu \& Una Osili, Beyond Grantmaking: An Investigation of Program-Related Investments by U.S. Foundations, 46 Nonprofit \& Voluntary Sector Q. 305, 307 (2017). "PRIs are uncommon, [comprising] less than 1 percent of private foundation distributions." Rachel Culley \& Jill R. Horwitz, Profits v. Purpose: Hybrid Companies and the Charitable Dollar, in A Subtle Balance: Expertise, Evidence, and Democracy in Public Policy and Governance, 1970-2010, at 158, 165 (Edward A. Parson ed., 2015). 
If PRIs are beneficial, why do foundations make so few of them? The main reason is that PRI has a broad definitional scope, and foundations may incur penalties if they misuse them. A PRI is defined as a foundation investment, the primary purpose of which is to accomplish religious, charitable, scientific, literary, and/or or educational purposes, and no significant purpose of which is the production of income or the appreciation of property. ${ }^{79}$ An investment qualifies if it significantly furthers the accomplishment of the private foundation's exempt activities, and if the investment would not otherwise have been made. ${ }^{80}$

Accordingly, PRI is essentially defined by reference to general social purposes, and its only material requirement is that the investment would not be made by a standard profit-maximizing firm because it involves a subsidy. The question, however, is how to determine whether an investment serves a charitable mission, and whether the investment would otherwise take place. There is no specific identification of a beneficiary, nor are there other measures indicating need to help foundations make this determination. Consequently, there is some uncertainty as to whether specific investments would count as PRIs. This uncertainty is not riskless for foundations. If a specific investment fails to qualify as a PRI, it may result in failure to meet the foundation's minimum distribution requirements, leading to substantial tax payments and, in extreme scenarios, the loss of tax-exempt status. Accordingly, it is not surprising that most foundations are reluctant to assume this responsibility. ${ }^{81}$

\footnotetext{
7926 U.S.C. $\$$ 4944(c) (2018); Treas. Reg. § 53.4944-3(a)(1) (2016).

80 Treas. Reg. \$ 53.4944-3(a)(2) (2016); Program-Related Investments, IRS, https://www. irs.gov/charities-non-profits/private-foundations/program-related-investments [https://perma. cc/34KS-B6VY] (last updated Feb. 13, 2020).

81 "Principally on account of its attendant uncertainty, however, the PRI has been roundly neglected by constitutionally cautious foundation managers." Benjamin N. Feit, What IRS Private Letter Rulings Reveal About Program-Related Investments, 23 Tax'n Exempts 3, 5 (2011). "L3C advocates believe this is because foundations find them too risky. The IRS may disallow a PRI if the investment does not advance a foundation's particular purpose. Having disallowed a PRI, the IRS may impose large excise taxes on the foundation and, in rare cases, personal liability on its managers." Culley \& Horwitz, supra note 78, at 165 (footnote omitted).
} 
Table 1: Program-Related Investments by Largest Foundations in 2011-2015

\begin{tabular}{|c|c|c|c|c|c|}
\hline Foundation & 2011 & 2012 & 2013 & 2014 & 2015 \\
\hline Gates & $\begin{array}{c}\$ 105,670,051 \\
(2.7 \%)\end{array}$ & $\begin{array}{c}\$ 38,474,529 \\
(1.0 \%)\end{array}$ & $\begin{array}{c}\$ 45,731,170 \\
(1.1 \%)\end{array}$ & $\begin{array}{c}\$ 40,881,049 \\
(0.9 \%)\end{array}$ & $\begin{array}{c}\$ 78,401,192 \\
(1.6 \%)\end{array}$ \\
\hline Ford & $\begin{array}{c}\$ 10,494,162 \\
(1.7 \%)\end{array}$ & $\begin{array}{c}\$ 18,369,070 \\
(13.7 \%)\end{array}$ & $\begin{array}{c}\$ 21,167,832 \\
(3.1 \%)\end{array}$ & $\begin{array}{c}\$ 14,995,571 \\
(2.4 \%)\end{array}$ & $\begin{array}{c}\$ 6,671,549 \\
(1.1 \%)\end{array}$ \\
\hline Getty & N/A & N/A & N/A & N/A & N/A \\
\hline $\begin{array}{l}\text { Johnson } \\
\text { (Robert W.) }\end{array}$ & $\begin{array}{c}0 \\
(0 \%) \\
\end{array}$ & $\begin{array}{c}\$ 4,158,333 \\
(1.1 \%) \\
\end{array}$ & $\begin{array}{c}\$ 7,603,787 \\
(1.7 \%) \\
\end{array}$ & $\begin{array}{c}\$ 18,637,879 \\
(3.9 \%)\end{array}$ & $\begin{array}{c}\$ 19,497,500 \\
(4.0 \%)\end{array}$ \\
\hline Lilly & N/A & N/A & N/A & N/A & N/A \\
\hline Hewlett & N/A & N/A & N/A & N/A & N/A \\
\hline Kellogg & $\begin{array}{c}0 \\
(0 \%)\end{array}$ & $\begin{array}{c}\$ 7,500,000 \\
(2.0 \%)\end{array}$ & $\begin{array}{c}\$ 1,000,000 \\
(0.3 \%)\end{array}$ & $\begin{array}{c}\$ 1,000,000 \\
(0.3 \%)\end{array}$ & $\begin{array}{c}\$ 5,500,000 \\
(1.4 \%)\end{array}$ \\
\hline Packard & $\begin{array}{c}\$ 20,504,750 \\
(6.5 \%)\end{array}$ & $\begin{array}{c}\$ 36,055,512 \\
(10.7 \%)\end{array}$ & $\begin{array}{c}\$ 17,915,951 \\
(5.3 \%)\end{array}$ & $\begin{array}{c}\$ 53,921,538 \\
(14.4 \%)\end{array}$ & $\begin{array}{c}\$ 43,295,662 \\
(11.5 \%) \\
\end{array}$ \\
\hline $\begin{array}{l}\text { Moore } \\
\text { (Gordon and } \\
\text { Betty) }\end{array}$ & $\begin{array}{c}0 \\
(0 \%)\end{array}$ & $\begin{array}{c}0 \\
(0 \%)\end{array}$ & $\begin{array}{c}\$ 1,400,000 \\
(0.5 \%)\end{array}$ & $\begin{array}{l}\$ 2,100,000 \\
(0.8 \%)\end{array}$ & $\begin{array}{c}0 \\
(0 \%)\end{array}$ \\
\hline $\begin{array}{l}\text { Bloomberg } \\
\text { Family }\end{array}$ & $\begin{array}{c}0 \\
(0 \%)\end{array}$ & $\begin{array}{c}0 \\
(0 \%)\end{array}$ & $\begin{array}{c}0 \\
(0 \%)\end{array}$ & $\begin{array}{c}\$ 1,500,000 \\
(1.0 \%)\end{array}$ & $\begin{array}{c}\$ 1,250,000 \\
(0.4 \%)\end{array}$ \\
\hline
\end{tabular}

This table shows the dollar amounts of program-related investments made by the ten largest foundations in 2011 to 2015, and the percentage of these investments out of the total qualifying distributions. Source: Forms 990-PF all accessed from ProPublica.

The law is not oblivious to this problem, and the PRI rules attempt to mitigate uncertainty by providing specific examples of qualifying investments. ${ }^{82}$ Consistent with my theory of social enterprise and hybrid organizations, most of the examples in the PRI rules involve businesses that transact with disadvantaged individuals or businesses. These include businesses that employ, or provide employment opportunities for, a substantial number of low-income persons from deteriorated urban

\footnotetext{
82 Treas. Reg. § 53.4944-3(b) (2016).
} 
areas $;{ }^{83}$ businesses that market agricultural products sourced from lowincome farmers in depressed rural areas; ${ }^{84}$ and a variety of low-cost providers of essential goods and services, such as vaccines sold in developing countries, ${ }^{85}$ recycling collection services in developing countries ${ }^{86}$ or child care services in low-income neighborhoods. ${ }^{87}$

Although the regulations add some useful clarity to the PRI regime, there remains substantial uncertainty in applying them. It is not clear, for example, what kind of area would qualify as a "deteriorated," "lowincome," or "depressed rural" area. Moreover, most of the PRI examples require that the investment be made only in circumstances where conventional sources of funds are unwilling to provide funds at reasonable rates. In practice, investors may disagree about whether funds are available at reasonable terms.

Foundations may apply to the Internal Revenue Service, requesting more detailed guidance as to whether specific investments qualify as PRI. Private letter rulings typically refer to specific income levels of the ultimate patron-beneficiaries, and may provide useful color on the extent to which the business transacts with disadvantaged persons. ${ }^{88}$ But applying for private letter rulings is cumbersome and expensive; the cost of a private letter ruling, including legal fees, was estimated (as of 2010) to range from $\$ 33,700$ to $\$ 58,700 .{ }^{89}$ The private letter ruling system is therefore not a satisfactory remedy for the uncertainty as to what counts as a PRI, especially because PRIs are often relatively small.

\footnotetext{
${ }^{83}$ Id. ex. 4.

${ }^{84}$ Id. ex. 6

${ }^{85}$ Id. ex. 11.

${ }^{86}$ Id. exs. $12-13$.

${ }^{87}$ Id. exs. 18-19.

${ }^{88}$ See I.R.S. Priv. Ltr. Rul. 200610020 (Mar. 10, 2006) (giving an example of a PRI in a social investment firm organized for investing in businesses in low-income communities owned or controlled by members of a minority or other disadvantaged group. The letter states, inter alia, that before making an investment, the social investment firm will verify that its investee is located in an area with a poverty rate of at least twenty percent or a tract for which the median household income does not exceed eighty percent of the statewide median household income); see also I.R.S. Priv. Ltr. Rul. 199943044 (Oct. 29, 1999) (demonstrating a PRI in a business that employs workers from a targeted population in economically depressed area with severe unemployment. In this case, the letter states that the business operates in a national priority development region designated by the government as economically depressed).

${ }^{89}$ Matthew F. Doeringer, Fostering Social Enterprise: A Historical and International Analysis, 20 Duke J. Comp. \& Int'1 L. 291, 318 (2010).
} 
Foundations thus face unique problems in verifying the social purpose of the firms in which they invest. While foundations, many of which are large institutions, may be better placed than dispersed investors to control a firm's mission via control or contract, such mechanisms still entail high transaction and monitoring costs. Accordingly, foundations would also benefit greatly from a legal form that would enable them to efficiently and reliably assess a firm's mission, and whether that mission falls within the rules governing PRIs.

\section{EvaluAting THE EXISTING LEGAL HyBRID FoRMS}

Legal hybrid forms have emerged in multiple jurisdictions to facilitate the formation of commercial firms with a social purpose. These forms parallel the three legal structures discussed in Section I.A. I discuss in detail a principal example of each the three types: (i) the benefit corporation, which serves a general social purpose; (ii) the Community Interest Company (CIC), which has a constraint on distribution; and (iii) the Italian social cooperative (Type B), which is used to create WISEs that employ their beneficiaries. ${ }^{90}$ The first model has been mostly inconsequential and may, in fact, be counterproductive. The second model, properly understood, is simply a solution to unduly restrictive legal regimes for nonprofit charities. The third model, although narrowly applied to WISEs, is actually the most effective one, and is also the only one that has attracted government subsidies or tax benefits - even though such benefits were among the primary motivations for legal hybrid forms. ${ }^{91}$

\footnotetext{
${ }^{90}$ Although legal hybrid forms are typically based on another underlying form, whether it is a corporation, an LLC, or an employee-owned cooperative, the underlying form is largely immaterial. The key issues are mechanisms that commit the firm to pursuing social missions.

${ }^{91}$ The initial motivation for the legal hybrid forms in the U.S., primarily the L3C, was to create a form that qualifies automatically for PRIs. Culley \& Horwitz, supra note 78, at 165; Edward Xia, Can the LC3 Spur Private Foundation Program-Related Investment?, 2013 Colum. Bus. L. Rev. 242, 244. However, the IRS has resisted such attempts because these forms provide insufficient assurance to the subsidy-provider - here, the government - that the firm pursues social missions effectively. See Culley \& Horwitz, supra note 78, at 164-67; J. William Callison \& Allan W. Vestal, The L3C Illusion: Why Low-Profit Limited Liability Companies Will Not Stimulate Socially Optimal Private Foundation Investment in Entrepreneurial Ventures, 35 Vt. L. Rev. 273, 273 (2010).
} 


\section{A. For-Profits with General Social Purpose: The Benefit Corporation}

All legal hybrid forms in the U.S. are organizations with a general social purpose. The most dominant form, which thirty-six states have adopted to date, is the benefit corporation. ${ }^{92}$ Although each state has its own version of the statute, most states have based their laws on the provisions of the Model Benefit Corporation Legislation (MBCL).$^{93}$ I discuss each of the main elements in turn.

(1) Social purpose in the organizational documents: Each benefit corporation must have a charter provision committing it to pursue a general public benefit, which is typically defined as "[a] material positive impact on society and the environment." 94 A benefit corporation may also identify one or more "specific public benefits" in its governing documents, ${ }^{95}$ such as environmental protection, promoting the arts and sciences, or even "conferring any other particular benefit on society." 96 Thus, the purpose of benefit corporations is framed in extremely general terms to include largely any benefit to any identifiable group. ${ }^{97}$

(2) Third-party standard: Most benefit corporation statutes (though not Delaware's) require that social impact be measured by a third-party standard. ${ }^{98}$ The third-party measurement is supposed to give a firm's consumers information on the quality of the firm's social impact, so they can decide whether to pay premiums for the firm's products. Although standards must be independent and transparent, ${ }^{99}$ criteria for third-party standards are very flexible.

\footnotetext{
${ }^{92}$ B Lab, supra note 8 . The other two principal legal forms in the U.S. are the Low-Profit Limited Liability Company (L3C) and the Flexible Purpose Corporation (FPC). The L3C was adopted by eight states, including Vermont, Illinois, and Michigan. A few states, such as California, adopted the FPC. For discussion of the L3C, see Culley \& Horwitz, supra note 78, at 161 .

${ }^{93}$ Mark J. Loewenstein, Benefit Corporations: A Challenge in Corporate Governance, 68 Bus. L. 1007, 1012-13 (2013).

${ }^{94}$ Model Benefit Corp. Legislation $§ 102 \&$ cmt. (B Lab 2017), https://benefitcorp.net/sites/default/files/Model\%20benefit\%20corp\%20legislation\%20_4_17_17.pdf [https://perma .cc/W5UB-C73B].

${ }^{95}$ Id. § 201(b).

${ }^{96}$ Id. $\$ 102$ (defining "[s]pecific public benefit").

97 The L3C and FPC have equally vague social purposes. See, e.g., Cal. Corp. Code $\S 2602$ (b)(1)(A) (Deering Supp. 2020); Vt. Stat. Ann. tit. 11, § 4162(1)(A) (2016).

${ }_{98}$ Model Benefit Corp. Legislation $\S \S 102$, 401(a)(2) (B Lab 2017).

${ }^{99}$ Dana Brakman Reiser, Theorizing Forms for Social Enterprise, 62 Emory L.J. 681, 725 (2013)
} 
Numerous standards have evolved to measure social and environmental performance. Problematically, many include a ragbag of so-called "sustainability" policies, ranging from environmental and social measures to corporate governance measures. Because it is impossible to accurately measure social impact, these standards are incredible and uninformative. ${ }^{100}$ First, it is unclear whether these standards evaluate the firm's efficiency (for example, by cutting energy costs) or the extent to which the firm undertakes profit-sacrificing projects that benefit society. Second, these standards often measure attributes (e.g., employee ownership of the firm) that are not necessarily desirable. Third, it is impossible to compare these standards because they are not standardized. ${ }^{101}$ The standards depend on subjective judgments, rather than objective criteria; therefore, there is scope for manipulation and even greenwashing.

(3) Disclosure requirements: Benefit corporations must publish annual reports that assess their efforts to pursue public benefits. ${ }^{102}$ The disclosure is supposed to mitigate greenwashing. But if social impact is difficult to measure and easy to manipulate, it is hard to see how such disclosures could be informative. More broadly, the effectiveness of disclosure has been subject to doubts even in areas that are easier to verify and report. ${ }^{103}$ It is unrealistic to expect consumers and public shareholders to meaningfully assess the causal relationship between a firm's actions and the achievement of social purposes. Moreover, there is no external audit requirement; ${ }^{104}$ thus, companies are able to report their own compliance with the third-party standards based on subjective evaluations. Therefore, the scope for manipulation in these annual reports is substantial. Finally, most companies regardless of legal form publish long reports on their CSR activities anyway — and these reports are largely viewed, internally, as marketing materials. ${ }^{105}$

(4) Fiduciary duties: Benefit corporation statutes typically include strong constituency provisions that require managers to consider the

\footnotetext{
${ }^{100}$ See Jill E. Fisch, Making Sustainability Disclosure Sustainable, 107 Geo. L.J. 923, $947-$ 52 (2019) (discussing the limitations of current disclosure practices).

101 Id. at 947.

102 Model Benefit Corp. Legislation $\S 401$ (a) (B Lab 2017). For FPC disclosure requirements, see Cal. Corp. Code $\S 3500$ (b) (Deering Supp. 2020).

${ }^{103}$ E.g., Omri Ben-Shahar \& Carl E. Schneider, The Failure of Mandated Disclosure, 159 U. Pa. L. Rev. 647, 651 (2011).

${ }^{104}$ Model Benefit Corp. Legislation § 401(c) (B Lab 2017).

${ }^{105}$ Fisch, supra note 100 , at 950.
} 
effects of any action or inaction on the interests of different stakeholders; ${ }^{106}$ these stakeholders include shareholders, customers and employees, the community in which the firm operates, the local and global environment, and any other group that the directors deem appropriate. ${ }^{107}$

This fiduciary duty may help alleviate the concern that the firm might be acquired by a profit-seeking investor that will discontinue the firm's social mission. However, this concern is primarily relevant to public corporations, and virtually all benefit corporations are private. Moreover, the fiduciary duty comes with costs. Wide managerial discretion to pursue social missions enables managers to promote their own interests. Without adequate monitoring, there is little reason to believe that managers would be dedicated to pursuit of public benefits.

The benefit corporation does allow derivative lawsuits by shareholders with more than two percent holdings against managers who fail to fulfill the firm's public benefits. ${ }^{108}$ However, it is doubtful that shareholders will undertake costly lawsuits to enforce public benefits. ${ }^{109}$ Moreover, the success of such lawsuits is improbable because directors have very wide discretion in weighing the interests of different stakeholders, and such discretion is protected by the business judgment rule, ${ }^{110}$ which means that courts will be hesitant to second-guess managers' judgment.

(5) Subsidy-lock: Standing alone, adoption of a legal hybrid form is insufficient; entrepreneurs could form as a hybrid organization, reap subsidies from altruistic subsidy providers, and convert the firm into a standard for-profit, absconding with the money. Benefit corporation statutes help lock in subsidies by incorporating a mandatory control mechanism. The termination of benefit corporation status must be approved by a qualified majority-typically two-thirds - of the shareholders. ${ }^{111}$ This provision gives one-third of the shareholders control

\footnotetext{
${ }^{106}$ For further discussion, see Reiser, supra note 99, at 694-98.

${ }^{107}$ Model Benefit Corp. Legislation $\S \S 301(a)$, 303(a) (B Lab 2017).

${ }^{108}$ Id. $\S 305(\mathrm{c})(2)(\mathrm{i})$

${ }^{109}$ Benefit corporations are expressly not liable for monetary damages for failure to create public benefits. Id. $\S 305$ (b). For a proposal to allow beneficiaries to sue benefit corporations, see Brett H. McDonnell, From Duty and Disclosure to Power and Participation in Social Enterprise, 70 Ala. L. Rev. 77, 110 n.203 (2018).

110 Model Benefit Corp. Legislation § 301(a), (e) (B Lab 2017).

${ }^{111}$ Id. $\S 105$. Likewise, at least two-thirds of each class of voting shares must approve any conversion by a closely held, for-profit corporation into an FPC or vice versa. Cal. Corp. Code $\S \S 1152$ (b), 3002, 3301 (Deering Supp. 2020).
} 
over the mission, even if the firm has diverse shareholders. The same commitment device could be created within existing legal forms; for example, by adding a charter provision that gives a nonprofit control over the firm's mission. ${ }^{112}$ However, the costs of verifying such provisions may be preclusive for dispersed shareholders, and therefore a mandatory subsidy lock may reduce the risk that such shareholders will provide a subsidy to firms that change course and forego the social mission. Despite this advantage, the subsidy lock does not create a credible assurance that the firm pursues its mission effectively.

$* * *$

None of the elements of benefit corporations provide sufficient assurance that firms that adopt it have incentives to pursue social missions effectively. Thus, there is a genuine risk that firms adopt the form simply to engender trust and convey the appearance of good citizenship.

The benefit corporation has been adopted at increasing rates. As of 2013, about 350 firms were formed as benefit corporations across the U.S. ${ }^{113}$ Roughly 1000 existed in $2014 ;{ }^{114}$ according to one of the founders of B Lab, there were about 7000 as of $2018 .{ }^{115}$

However, a cursory look at many of these firms suggests that the benefit corporation is an old idea in new clothes. The form has been adopted by retailers and consulting firms seeking to improve their public image or adopt practices that make commercial sense. These companies may undertake desirable initiatives, but it is unlikely that they create social impact beyond what standard corporations already provide. ${ }^{116}$ Consumers that trust these firms to do good things and pay premiums for their products rely on personal knowledge of these firms rather than the

${ }^{112}$ For discussion of the validity of such a provision, see supra text accompanying notes 5969. For examples of control mechanisms, see Eldar, supra note 10, at 154-57.

${ }^{113}$ Alicia E. Plerhoples, Delaware Public Benefit Corporations 90 Days Out: Who's Opting In?, 14 U.C. Davis Bus. L.J. 247, 250 (2014).

114 Kate Cooney et al., Benefit Corporation and L3C Adoption: A Survey, Stan. Soc. Innovation Rev. (Dec. 5, 2014), https://ssir.org/articles/entry/benefit_corporation_and_13c_adoption_a_survey [https://perma.cc/9CBM-STXJ].

115 Jay Coen Gilbert, Sen. Elizabeth Warren, Republicans, CEOs \& BlackRock's Fink Unite Around 'Accountable Capitalism,' Forbes (Aug. 15, 2018), https://www.forbes.com/sites/jaycoengilbert/2018/08/15/sen-elizabeth-warren-republicans-ceos-blackrocks-finkunite-around-accountable-capitalism/\#4730f51251d9 [https://perma.cc/H5LF-AJX6].

${ }^{116}$ For example, Toms Shoes donates shoes to the poor in developing countries, but it is not incorporated as a benefit corporation. 
legal form. For example, Patagonia and the Greyston Bakery were wellknown for environmental and social policies well before they became benefit corporations. Conversely, Laureate Education gained its status because it operates universities in developing countries; however, its business model appears largely profit-driven because its compensation structure is based on increasing enrollment. ${ }^{117}$ Thus, status as a benefit corporation is not a reliable indicator that a company creates public benefits. As more firms adopt the benefit corporation form, it will likely be more difficult to distinguish between firms that engage in greenwashing and fanciful charity projects versus those that employ subsidies effectively.

Moreover, the social purpose requirement of benefit corporations has, so far, failed to facilitate the creation of public firms that promote social goals. ${ }^{118}$ A possible important reason is that it does not signal to investors that the firm truly needs subsidies to pursue social mission, nor that the firm will use subsidies effectively. Without this information, altruistic public investors lack the means for identifying firms that have genuine social impact.

\section{B. Organizations with a Constraint on Distribution: The Community Interest Company}

Unlike the hybrid legal forms in the U.S., most European and Canadian forms are defined by some kind of distribution constraint. These forms are variants of the nonprofit form, except that the constraint on distribution may be partial rather than total. I focus on the U.K.

${ }^{117}$ Eldar, supra note 10, at 99; Laureate Educ., Inc., Registration Statement (Form S-1) 273, 277 (Dec. 15, 2016), https://www.sec.gov/Archives/edgar/data/912766/000104746916017211/a2228849zs-1a.htm [https://perma.cc/UZ67-LUWL]. Laureate Education also appears to have created indebtedness for its students in several regions. Janet Lorin, Laureate's U.S. Students Struggling To Repay Loans As IPO Looms, Bloomberg (Nov. 4, 2015), https://www.bloomberg.com/news/articles/2015-11-04/laureate-loan-repayment-rate-showsu-s-debt-burden-as-ipo-looms [https://perma.cc/3CQT-4AUF]; see also Steven Davidoff Solomon, Idealism That May Leave Shareholders Wishing for Pragmatism, N.Y. Times (Oct. 14, 2015), https://nyti.ms/1jveRAh [https://perma.cc/PY5N-MB4G] ("Given the vagueness here, instead of being a force for good, Laureate's benefit may simply result in greenwashing, that is, use of a public-relations-enhancing social purpose to fritter away money without oversight.").

118 For example, Etsy, a public corporation, recently rescinded its promise to become a benefit corporation. David Gelles, Inside the Revolution at Etsy, N.Y. Times (Nov. 25, 2017), https://www.nytimes.com/2017/11/25/business/etsy-josh-silverman.html [https://perma.cc/Y9Z8-SMQ4]. 
Community Interest Company (CIC). ${ }^{119}$ Other similar laws have now been adopted in Canada, ${ }^{120}$ Italy, ${ }^{121}$ Belgium, ${ }^{122}$ France, ${ }^{123}$ Spain, ${ }^{124}$ and others. ${ }^{125}$ Although the exact rules of each form vary, the key elements are the distribution constraint and asset lock.

(1) Distribution Constraint: The main feature of the CIC is that it is subject to some constraint on distributing profits. The constraint may be absolute (if the company is limited by a guarantee) or partial (if the company is limited by shares). If limited by shares, the company is subject to a distribution cap. Specifically, it cannot distribute dividends greater than five percent over the Bank of England base lending rate. ${ }^{126}$ Moreover, the total dividend may not exceed thirty-five percent of

${ }^{119}$ See Companies (Audit, Investigations and Community Enterprise) Act 2004, c. 27, § 26 (U.K.), http://www.legislation.gov.uk/ukpga/2004/27/pdfs/ukpga_20040027_en.pdf?view=extent [https://perma.cc/Y87X-8ZQS].

120 See, e.g., Community Interest Companies Act 2012, S.N.S. 2016, c 38 (Can.); Community Contribution Company Regulation, B.C. Reg. 63/2013 (Can.) (providing one example of such laws).

121 See Fabrizio Cafaggi \& Paola Iamiceli, New Frontiers in the Legal Structure and Legislation of Social Enterprises in Europe: A Comparative Analysis 7 (Eur. Univ. Inst. Dep't of Law, Working Paper No. 2008/16, 2008), http://cadmus.eui.eu/bitstream/handle/1814/8927/LAW_2008_16.pdf?sequence=3\&isAllowed=y [https://perma.cc/D79U-TBR2] (describing Italian Type A Cooperative and Italian Social Enterprise).

${ }^{122}$ Doeringer, supra note 89, at 308-09 (describing Belgian social enterprise companies, including a corporate form called the Société à Finalité Sociale (SFS), also called a CSP in English-speaking countries).

${ }^{123}$ European Comm'n, A Map of Social Enterprises and Their Eco-systems in Europe, Country Report: France 6, 25-26 (2014), https://ec.europa.eu/social/BlobServlet?docId=13024\&langId=en [https://perma.cc/64JZ-HFND] [hereinafter Country Report: France] (describing the French Société Coopérative d'Intérêt Collectif (SCIC) and the Social and Solidarity Economy (SSEs)).

${ }^{124}$ European Comm'n, Social Enterprises and Their Eco-systems in Europe: A European Mapping Report, Updated Country Report: Spain 35, 39 (2016), https://ec.europa.eu/social/BlobServlet?docId=16383\&langId=en [https://perma.cc/EE6Z-7ALF] [hereinafter Country Report: Spain] (describing Spanish Social Initiative Cooperatives).

${ }^{125}$ In many European countries, the form is based on employee-owned cooperatives. These forms are not true cooperatives because their beneficiaries need not be-and typically are not - the members. See Henry Hansmann, The Ownership of Enterprise 12 (1996) (defining cooperatives as organizations owned by their beneficiary-members who are often the consumers of these organizations); Org. Econ. Co-operation \& Dev., The Changing Boundaries of Social Enterprise 32 (Antonella Noya ed., 2009) ("This means that, by definition, the social co-operative is not a mutual organisation, like an ordinary co-operative, but it is generally directed towards providing benefits to external beneficiaries, as distinct from its members."). Employee ownership, in this context, is not designed to ensure that the firm does not exploit the employees, but to prevent outside investors from acquiring the firm and changing its social mission.

${ }^{126}$ Doeringer, supra note 89 , at 312 . 
distributable profits. ${ }^{127}$ Thus, the company has to re-invest profits in the business. ${ }^{128}$

The constraint on distribution works like a nonprofits' distribution ban, though presumably to a lesser extent. It is designed to ensure that those who control the CIC have limited incentives to make profit, which makes it more likely that they will pursue non-pecuniary goals. However, as discussed above, it is of limited utility in designing firms that can serve as an effective conduit for subsidies; it only works well when the organization does not face information asymmetries with respect to its beneficiaries.

(2) Subsidy-lock: Distribution constraints must go hand-in-hand with some rule that prevents the organization from shifting its assets to another entity that could distribute them. Otherwise, managers could circumvent the distribution constraint by shifting assets to another company and then distributing the subsidies to themselves. Accordingly, CICs may not dispose of their assets for less than their fair market value, except in pursuit of their community benefits or in a transfer to a charity or another CIC. ${ }^{129}$ On dissolution, assets may not be paid out to directors, members, or equity holders. Rather, all assets must go to another entity whose assets are perpetually devoted to community benefit. ${ }^{130}$

(3) Additional elements: Legal forms with distribution constraints typically include additional features that characterize legal forms with a

\footnotetext{
${ }^{127} \mathrm{Id}$.

${ }^{128}$ Similar rules apply to other forms, such as Belgian CSPs, see European Comm'n, A Map of Social Enterprises and Their Eco-systems in Europe, Country Report: Belgium 32-38 (2014), https://ec.europa.eu/social/BlobServlet?docId=13276\&langId=en [https://perma.cc/BN8R-5ENQ] [hereinafter Country Report: Belgium], and Italian Type A social cooperatives, see European Comm'n, A Map of Social Enterprises and Their Eco-systems in Europe, Country Report: Italy 18 (2014), https://ec.europa.eu/social/BlobServlet?docId=13026\&langId=en [https://perma.cc/3NSC-P2UZ] [hereinafter Country Report: Italy].

129 Office of the Regulator of Cmty. Interest Cos., Information and Guidance Notes $\S 6.1$ (2016), https://assets.publishing.service.gov.uk/government/uploads/system/uploads/attachment_data/file/605418/14-1089-community-interest-companies-chapter-6-the-asset-lock.pdf [https://perma.cc/WT5P-3GNS]; see also Companies (Audit, Investigations and Community Enterprise) Act 2004, c. 27, § 30 (U.K.).

130 Office of the Regulator of Cmty. Interest Cos., Information and Guidance Notes $\S 10.5 .2$ (2016), https://assets.publishing.service.gov.uk/government/uploads/system/uploads/attachment_data/file/605422/13-712-community-interest-companies-chapter-10-transfer-of-assetsand-ceasing-to-be-a-cic.pdf [https://perma.cc/FL24-VYT3]. Similar restrictions apply to European forms. See Country Report: Belgium, supra note 128, at 25 (discussing Belgian CSPs); Country Report: France, supra note 123, at 67 (discussing French SCICs and SSEs); Cafaggi \& Iamiceli, supra note 121, at 7-8 (discussing Italian cooperatives and Italian social enterprises.
} 
general social purpose. Specifically, the entity must have a specified social purpose. This is very similar to standard nonprofit firms, whichby law-must serve one or more specific purposes, such as religious, charitable, educational, or literary. U.K. CICs must meet the community interest test, which requires that "a reasonable person might consider [the CIC's] activities are being carried on for the benefit of the community."131 CICs must be certified by the CIC Regulator, which examines whether the applicants meet the community interest test. ${ }^{132}$ They are also subject to disclosure requirements; they must report their community interest achievements to the Regulator annually. ${ }^{133}$ The report must "confirm that access to the benefits [the CIC] provides will not be confined to an unduly restricted group."134 As discussed above, however, these elementsindividually or jointly - are not likely to serve as an adequate assurance mechanism to subsidy providers. The community interest test is vague and imprecise, and disclosure requirements are not useful if social impact cannot be well-measured. Accordingly, it is unlikely that forms with distribution constraints serve as effective vehicles for utilizing subsidies.

$$
* * *
$$

Despite their imperfections, forms with distribution constraints serve an important function in some jurisdictions. Over 14,000 firms have registered as CICs since 2004. ${ }^{135}$ Why have these forms proliferated in some parts of Europe? These forms arose in jurisdictions that limit the

${ }^{131}$ Companies (Audit, Investigations and Community Enterprise) Act 2004, c. 27, § 35(2) (U.K.).

${ }^{132}$ Dana Brakman Reiser, Governing and Financing Blended Enterprise, 85 Chi.-Kent L. Rev. 619, 633 (2010).

${ }^{133}$ Disclosure requirements vary across jurisdictions. See, e.g., Country Report: Belgium, supra note 128, at 40 (Belgian CSPs must publish annual reports on the relation of their expenses with their mission); Cafaggi \& Iamiceli, supra note 121, at 27 (Italian social enterprises have discretion over form and scope of disclosure).

${ }^{134}$ Office of the Regulator of Cmty. Interest Cos., Frequently Asked Questions 14 (2017), https://assets.publishing.service.gov.uk/government/uploads/system/uploads/attachment_dat a/file/641412/13-786-community-interest-companies-frequently-asked-questions.pdf [https://perma.cc/5CCU-BEG5].

135 Office of the Regulator of Cmty. Interest Cos., Annual Report 2017-18, at 3 (2018), https://assets.publishing.service.gov.uk/government/uploads/system/uploads/attachment_dat a/file/727053/cic-18-6-community-interest-companies-annual-report-2017-2018.pdf [https://perma.cc/C5WA-K9LP] [hereinafter CIC Annual Report]; see also Jacques Defourny \& Marthe Nyssens, Social Enterprise in Europe: Recent Trends and Developments, 4 Soc. Enterprise J. 202, 205-06 (2008) (explaining the importance of these companies to the British and Italian economies). 
commercial activities of nonprofit charities. Unlike U.S. law, English charity law ${ }^{136}$ makes it difficult for charities to engage in commercial activity. Charities that want to undertake substantial commercial activity must form a trading company, which may only donate money, rather than distribute dividends, to the charity. ${ }^{137}$

Relatedly, these forms are mainly used by firms in services such as healthcare and education. ${ }^{138}$ Such firms provide complex services that consumers may have difficulty evaluating. The CIC and similar forms are designed to prevent managers from exploiting consumers who cannot assess the quality of their products. ${ }^{139}$ Thus, they are akin to commercial nonprofits in the U.S., which engage mainly in providing healthcare and social services. ${ }^{140}$ This role does not necessarily entail a subsidy; thus, the adoption of the form is not typically intended to ensure effective use of subsidies. While there are some CICs that transfer subsidies to beneficiaries, ${ }^{141}$ they tend to be small, private firms ${ }^{142}$ that rely on control devices created by altruistic investors who are well-positioned to monitor the use of the subsidies. The CIC form is unlikely to assure dispersed subsidy providers that their subsidies are used effectively without substantial diligence and monitoring. Likewise, although the government

${ }^{136}$ Similar restrictions appear in other jurisdictions. See, e.g., Carlo Borzaga \& Alceste Santuari, Italy: From Traditional Co-operatives to Innovative Social Enterprises, in The Emergence of Social Enterprise 166, 169 (Carlo Borzaga \& Jacques Defourny eds., 2001) (explaining that Italian nonprofits may not carry out "productive" activities such as social services).

${ }^{137}$ Doeringer, supra note 89 , at $311-12$.

${ }^{138}$ CIC Annual Report, supra note 135, at 5. This trend is reflected in other similar forms. See, e.g., Country Report: Italy, supra note 128, at 24; Country Report: Spain, supra note 124, at 24; Younes Sebbarh, The Belgian Social Purpose Company: Maintain, Adjust or Abandon? 70 (May 2017) (unpublished M.A. thesis, Catholic University of Leuven), https://6emesconf.exordo.com/files/papers/56/final_draft/YounesSebbarh-Thesis-Arial.pdf [https://perma.cc/2RVE-3M8A].

${ }^{139}$ See supra text accompanying notes 59-62.

${ }^{140}$ Molly F. Sherlock \& Jane G. Gravelle, Cong. Research Serv., R40919, An Overview of the Nonprofit and Charitable Sector 4 (2009) ("More than half of nonprofit employment (approximately 54\%) is involved in health care and social assistance.").

${ }^{141}$ See, e.g., Office of the Regulator of Cmty. Interest Cos., Case Study: Bookdonors (Nov. 12, 2013), https://www.gov.uk/government/case-studies/bookdonors [https://perma.cc/R6VR-DUKH] (describing a firm that sells donated secondhand books and donates profits to charity); Office of the Regulator of Cmty. Interest Cos., Case Study: Warm Wales (Cymru Gynnes) (Nov. 12, 2013), https://www.gov.uk/government/case-studies/warm-wales-cymrugynnes [https://perma.cc/M7CU-22HG] (describing a firm that provides products - such as affordable heating and insulation - in impoverished areas).

${ }^{142}$ There seems to be no example of a CIC with public shares and all the main examples of CICs discussed in the CIC Annual Report, supra note 135, are small companies. 
has considered giving CICs some tax relief, ${ }^{143}$ these initiatives have not materialized. Again, this is likely because the form on its own does provide sufficient assurance to the government that it accomplishes a tangible benefit that requires a subsidy.

\section{Social Enterprises That Transact with Their Beneficiaries: The WISE Legal Form}

Finally, a large set of European forms are social enterprises that transact with their beneficiaries. These organizations are almost universally work-integration social enterprises (WISEs); that is, they employ disadvantaged workers that would otherwise be unemployed.

These organizations may take many legal forms. The discussion below focuses on the Italian Type B social cooperative — one of the most popular forms for WISEs ${ }^{144}$ _ but other jurisdictions have similar forms, such as the Finnish Social Enterprise Law, ${ }^{145}$ the Spanish Social Integration Enterprises (EIs), ${ }^{146}$ and the French work integration enterprises. ${ }^{147}$ The statutory purpose of the Type B social cooperative is to integrate disadvantaged workers through professional and personal development. ${ }^{148}$ The disadvantaged workers are not required to be members of the cooperative. The members are usually other employees, volunteers, and some funders and public institutions. The social cooperative is thus not a true cooperative because its beneficiaries need

143 Astrid Zweynert, UK Boosts Social Enterprise with 30 Pct Tax Relief on Social Investments, Thomson Reuters (Mar. 19, 2014), http://www.trust.org/item/2014032000003795mrd/?source=hpbreaking [https://perma.cc/3NFQ-MS2U].

${ }^{144}$ Italian social cooperatives may be Type A or Type B. Type B is specifically designed for forming WISEs. Country Report: Italy, supra note 128, at 1 ("The law distinguishes between two types of social cooperatives: Social cooperatives supplying social, health and educational services (defined by law as type A social cooperatives); and Social cooperatives integrating disadvantaged groups into the labour market (type B social cooperatives).”).

${ }^{145}$ European Comm'n, A Map of Social Enterprises and their Eco-systems in Europe, Country Report: Finland 31 (2014), https://ec.europa.eu/social/BlobServlet?docId=13102\&langId=en [https://perma.cc/XG4L-8522] [hereinafter Country Report: Finland]; Cafaggi \& Iamiceli, supra note 121, at 22.

146 Richard Pfeilstetter \& Itziar Gómez-Carrasco, Social Enterprises in Spain: Country Report 3-4 (2017), http://www.lasociedadcivil.org/wp-content/uploads/2017/12/Pfeilstetter_GomezCarrasco.pdf [https://perma.cc/TFE9-M5WH].

147 Elisabetta Bucolo, French Social Enterprises: A Common Ethical Framework To Balance Various Objectives, in Social Enterprise: At the Crossroads of Market, Public Policies and Civil Society 59, 60 (Marthe Nyssens ed., 2006).

${ }^{148}$ Cafaggi \& Iamiceli, supra note 121 , at 7. 
not be (and typically are not) the members. ${ }^{149}$ Rather, it is a conduit for subsidies - from investors, consumers, the government, and even the workers who are not disadvantaged - to the disadvantaged workers. The facilitation of WISEs primarily through cooperatives is an idiosyncratic feature of European systems.

The development of WISEs in Europe illustrates the substitutability of legal forms and pure certification mechanisms. In some jurisdictions, WISEs are created by statute as legal forms, as in Italy. ${ }^{150}$ Elsewhere, as in Finland, different legal entities may apply to a government agency for certification as WISEs. ${ }^{151}$ Whether the certification is embedded in the legal form or in a separate law, the organization can use its status as a commitment device to potential subsidy providers. Unlike the other legal forms, WISEs benefit from government subsidies because they presumably generate tangible social impact-employment of the disadvantaged. I discuss each of the main elements of the WISE legal forms below.

(1) Certification of the transaction with the worker-beneficiaries: First, there must be some criteria for determining which workers are disadvantaged. For the Italian Type B cooperative, workers who qualify as disadvantaged include workers who have mental or physical disabilities, drug addicts, alcoholics, minors with family problems, and prisoners on probation. ${ }^{152}$ These cooperatives either provide a stable job for disadvantaged people or train them so that they can later find a job elsewhere in the market. In either case, disadvantaged workers are certified as such only temporarily; ${ }^{153}$ hence, the firm has to continuously employ and train new workers to maintain its status. This is designed to make sure that the firm does not expropriate subsidies by employing workers who are no longer disadvantaged.

Second, a threshold number of workers must be disadvantaged. At least thirty percent of the workforce of Italian Type B cooperatives must be

\footnotetext{
${ }^{149}$ See supra note 125 .

${ }^{150}$ See Country Report: Italy, supra note 128 , at i.

${ }^{151}$ Any type of organization may apply to the Ministry of Employment and the Economy to be included in the Registry of Work Integration Social Enterprises. Country Report: Finland, supra note 145 , at 17,31 .

${ }_{152}$ Country Report: Italy, supra note 128 , at 1 n.2.

${ }^{153}$ Carlo Borzaga \& Monica Loss, Multiple Goals and Multi-Stakeholder Management in Italian Social Enterprises, in Social Enterprise: At the Crossroads of Market, Public Policies and Civil Society 72, 75 (Marthe Nyssens ed., 2006).
} 
disadvantaged. ${ }^{154}$ Other WISE legal forms must meet similar thresholds, ${ }^{155}$ though some are subject to higher requirements, ${ }^{156}$ and some even assign different requirements for each type of WISE in accordance with the level of need. ${ }^{157}$ These requirements ensure that the firm has a significant stake in the development of its workers. If a large number of workers does not perform, the firm will not be able to produce high-quality products or services.

(2) The terms of the transactions with the beneficiaries: Interestingly, the Italian Type B cooperative is not required to pay fair wages or provide employees with a favorable working environment. ${ }^{158}$ To address the concern that such WISEs exploit their disadvantaged workers, Italian law subjects them to a distribution constraint. Distribution of profits is limited to $2.5 \%$ above the postal bond rates, ${ }^{159}$ and at least $30 \%$ of the annual net profits must be allocated to a reserve fund. ${ }^{160}$ This constraint may mitigate the incentives to exploit the workers by, for example, paying egregiously low salaries. Thus, a distribution constraint serves as a substitute for regulating the terms of the transaction between the firm and its beneficiaries. While most European social enterprise forms subject WISEs to such a constraint, Finland takes a different approach by allowing for-profits to qualify as social enterprises. But Finnish law requires workers be paid a salary of an "able-bodied" person, regardless of the worker's productivity. ${ }^{161}$

(3) Subsidy-lock: As social cooperatives, the Italian WISEs are subject to a mandatory governance structure. Its main feature is a one-member, one-vote system not based on the capital contribution. ${ }^{162}$ This structure serves as a control mechanism by making it difficult for any investors to

\footnotetext{
${ }^{154} \mathrm{Id}$.

${ }^{155}$ See, e.g., Country Report: Finland, supra note 145, at 17 (indicating a thirty percent threshold for Finnish WISEs).

${ }^{156}$ See, e.g., Pfeilstetter \& Gómez-Carrasco, supra note 146, at 4-5 (indicating a thirty percent threshold rising to fifty percent after three years for Spanish EIs).

${ }^{157}$ For example, Spanish Special Employment Centers must employ severely disadvantaged workers in a long-term capacity as at least seventy percent of their workforce. Id. at 4.

${ }^{158}$ See Carlo Borzaga, Italy: The Impressive Development of Social Co-operatives in Italy, in Tackling Social Exclusion in Europe 181, 195 (Roger Spear et al. eds., 2001).

${ }^{159}$ Country Report: Italy, supra note 128 , at 34 .

${ }^{160}$ Id. at 35 .

161 Cafaggi \& Iamiceli, supra note 121, at 23. As discussed infra Section IV.G, requiring WISEs to pay wages above the minimum wage may be counterproductive if it dissuades them from employing disadvantaged people.

${ }^{162}$ Country Report: Italy, supra note 128 , at 18.
} 
expropriate subsidies by converting the firm to a for-profit and distributing the subsidies to themselves. The cooperative form, however, is a burdensome commitment device because it may create inefficiencies in decision-making if members have disagreements as to how a social mission ought to be pursued. ${ }^{163}$ Further, it places a major burden on the firm's ability to raise capital. ${ }^{164}$ Therefore, this approach to commitment device creation is likely sub-optimal, and induced by the special role that cooperatives play in European jurisdictions.

(4) Additional elements: WISE-type forms include additional elements that characterize the other legal forms, but do not add much beyond the requirement to employ disadvantaged workers. They typically include a statutory statement of a social purpose. For example, social cooperatives in Italy must pursue the general interests of the community in human promotion and in the citizens' social integration. ${ }^{165}$

$$
* * *
$$

Overall, the European WISEs appear to be effective mechanisms for improving employment opportunities. First, although they are focused on a very specific type of mission and are subject to strenuous requirements, they are very popular. ${ }^{166}$ Not surprisingly, they mostly operate in industries that require relatively low-skill workers, such as food services and maintenance. Second, although they may have difficulty raising capital, WISEs seem to attract investments from a variety of altruistic investors, such as banks dedicated to fostering development. ${ }^{167}$ This suggests that the legal form is well-equipped to assure investors that it uses subsidies effectively. Third, WISEs tend to receive substantial government subsidies. ${ }^{168}$ Italian law gives WISEs preferential treatment

\footnotetext{
${ }^{163}$ See Hansmann, supra note 125, at 40-42 (discussing the costs of collective decision making).

${ }^{164}$ For difficulties in raising capital, see, e.g., id. at 140 (describing the difficulties of farming cooperatives to maintain adequate investment).

${ }^{165}$ Cafaggi \& Iamiceli, supra note 121, at 7.

${ }^{166}$ See, e.g., Country Report: France, supra note 123, at 30 (estimating roughly 4000 WISEs operating in France in 2010); Borzaga \& Loss, supra note 153, at 76 (noting that Italian Type B social cooperatives increased from 287 in 1993 to 1,915 in 2000).

167 Antonio Thomas, The Rise of Social Cooperatives in Italy, 15 Voluntas: Int'l J. Voluntary \& Nonprofit Orgs. 243, 257-60 (2004).

${ }^{168}$ See Country Report: Italy, supra note 128 , at 49 (stating that subsidies provide up to sixty percent of the cost of labor of the social enterprise).
} 
in tendering. ${ }^{169}$ Thus, the government consumes many of the services that WISEs provide. ${ }^{170}$ Other countries provide subsidies in the form of contributions toward workers' salaries. ${ }^{171}$ In contrast, none of the other types of legal forms are trusted by their respective public authorities as a vehicle for transferring subsidies. ${ }^{172}$ Again, this suggests that the commitment to transacting with disadvantaged individuals serves as a credible signal to subsidy-providers that their subsidies are effectively used. Most importantly, the available evidence suggests that WISEs are effective in integrating disadvantaged people into the workforce and helping workers improve their occupational skills. ${ }^{173}$

The main limitation of the European WISE forms is that the WISEs seem to be almost invariably small firms in very few industries. Naturally, employing disadvantaged people places severe restrictions on the firm's ability to expand and grow. But there are likely other reasons. First, some of the requirements under European law may be too restrictive, focusing on workers with severe problems rather than poorer regions that suffer from systemic unemployment despite an abundance of capable workers. Second, WISEs are usually restricted to the cooperative form or forms that are subject to a distribution constraint; therefore, their ability to source capital from investors is limited. If WISEs are committed to employing a certain class of workers and cannot easily change this commitment, there are limited reasons to deny them the ability to distribute profits - particularly if subsidies are forthcoming from other sources, primarily consumers and the government. Third, the government provides no special mark for WISEs to attach to their products, making

\footnotetext{
${ }^{169}$ Id. at 4 ("When the law on social cooperatives was passed, it granted social co-operatives the status of preferred providers in local authority procurement. While this has subsequently been challenged, an exemption for 'type B' social co-operatives was agreed with the European Commission, which allows local authorities to enter into direct agreements with them for contracts up to $€ 300,000$.").

${ }^{170}$ Laurent Gardin, A Variety in Resource Mixes inside Social Enterprise, in Social Enterprise: At the Crossroads of Market, Public Policies and Civil Society 111, 117 (Marthe Nyssens ed., 2006).

${ }^{171}$ See. e.g., Country Report: Finland, supra note 145, at 8 (stating that social enterprises receive subsidies from the government per each disadvantaged worker they employ, which can cover up to fifty percent of salary costs); Nathalie Lallemand-Stempak et al., Field Description in Work Integration, 9 (2015), http://itssoin.eu/site/wp-content/uploads/2015/09/ITSSOIN_D7_1_Part-1_Field-description_Work-Integration.pdf [https://perma.cc/HDM8-XQNE] (stating that French Work Integration Enterprises (EIs) receive a fixed subsidy from the state for each disadvantaged worker they hire in a full-time position).

${ }^{172}$ See supra Section II.B.

${ }^{173}$ See Borzaga, supra note 158, at 194, 197-98.
} 
consumers less likely to pay premium prices for the firm's products because they are not well-informed about the mission of the firm.

\section{Corporate Subsidy Programs as Public Certification MECHANISMS}

The proliferation and apparent effectiveness of legal forms that facilitate WISEs throughout Europe reinforces that legal forms could be more effective if they focused on firms that commit to transacting with different classes of beneficiaries. It also demonstrates that, ultimately, these forms serve as public certification mechanisms. Just like the nonprofit form certifies that a firm is subject to the non-distribution constraint, a legal form - such as the WISE - confirms that a firm is committed to transacting with a class of disadvantaged groups.

Public certification is not only embedded in legal forms, but is also a key feature of corporate subsidy programs. Corporate subsidy programs typically involve certification procedures that make firms eligible for certain public subsidies. The WISE legal forms may be viewed as corporate subsidy programs that certify WISEs; even the nonprofit form essentially makes firms eligible for tax subsidies based on certification of the non-distribution constraint. Accordingly, corporate subsidies need to be considered in designing a legal form for firms that transact with disadvantaged groups.

The American system does, in fact, have a corporate subsidy program that seems to work particularly well: community development financial institutions (CDFIs). CDFIs - which have been operating for more than two decades - have had substantial success increasing access to capital in depressed communities and enabling low-income people to become homeowners through mortgage lending. ${ }^{174}$ CDFIs' basic structure is based on government certification of their transactional relationships with low-income communities. As I argue below, the key elements of the CDFI regime could form the basis for a broader certification and legal form for social enterprises that transact with their beneficiaries.

The CDFI regime also demonstrates the need for public certification to enable the government to allocate subsidies and tax benefits to

174 Mark Pinsky, Taking Stock: CDFIs Look Ahead After 25 Years of Community Development Finance, Brookings Inst. (Dec. 1, 2001), https://www.brookings.edu/articles/taking-stock-cdfis-look-ahead-after-25-years-of-community-development-finance/ [https://perma.cc/59DA-EBQP]. 
organizations. The CDFI certification is primarily designed to assist the government in allocating tax subsidies to organizations with structures that incentivize them to use subsidies effectively. CDFI certification entitles financial institutions to receive subsidized funding and various tax credits from the CDFI Fund. This is broadly consistent with the European approach to WISEs and the tax treatment of nonprofits, properly viewed as a certification mechanism.

In the first Section below, I describe the CDFI regime in detail, and explain why it serves as an effective template for legal hybrid forms. In the second Section, I explain how the CDFI regime differs from other certification mechanisms that seem to serve similar purposes, specifically the laws that certify credit unions and the Work Opportunity Tax Credit. I further explain how the CDFI regime differs from an alternative policy that rests on the obligation (rather than a voluntary commitment) to transact with disadvantaged groups as manifested in the Credit Reinvestment Act.

\section{A. CDFIs as a Template for Legal Hybrid Forms}

The CDFI Fund was established in 1994 to promote economic revitalization and community development in low-income communities. ${ }^{175}$ It certifies two types of organizations that facilitate financing to low-income individuals: CDFIs and community development entities (CDEs), which are not financial institutions. The CDFI Fund uses federal resources to invest in CDFIs and build their capacity to serve low-income communities that lack access to affordable financial products and services. ${ }^{176}$ It also uses a merit-based process to provide CDFIs with different types of awards - specifically financial assistance in the form of equity investments, loans, or grants - and technical assistance. ${ }^{177}$ Firms certified as CDEs may qualify for the New Markets Tax Credit (NMTC), a tax credit offered to CDEs' equity investors. While the CDFI program

\footnotetext{
17512 U.S.C. $\$$ 4701(b) (2018). The CDFI Fund is a wholly owned government corporation in the executive branch. Id. § 4703(a)(2).

176 See CDFI Program, CFDI Fund, https://www.cdfifund.gov/programs-training/Programs/cdfi-program/Pages/default.aspx [https://perma.cc/3VX9-T6X3] (last visited Jan. 1, 2019) (describing CDFI Fund application requirements).

177 See infra Part V.
} 
is a federal subsidy program, many CDFIs also raise capital from social investors, financial institutions, and foundations. ${ }^{178}$

(1) Certification of the transaction with the beneficiaries: In order to obtain the certification, the applicant must meet three criteria. First, the applicant must have a primary mission of promoting community development. ${ }^{179}$ Second, the applicant must either (i) serve an "[i]nvestment [a]rea," which is an area that meets at least one of the developed criteria of economic distress ${ }^{180}$ or otherwise "has significant unmet needs for loans or equity investments;" 181 or (ii) serve a "targeted population," which is an identifiable group of individuals who are lowincome persons ${ }^{182}$ or "otherwise lack adequate access to loans or equity investments." 183 Third, the applicant must provide development services ${ }^{184}$ in conjunction with its financing activities.

CDFIs must also demonstrate that they transact with low-income groups at sufficient scale. In determining whether an applicant's primary mission is to promote development, the CDFI Fund must consider whether the applicant's activities are "purposefully directed toward improving the social and/or economic conditions of underserved people (which may include Low-Income persons and persons who lack adequate access to capital and/or Financial Services) and/or residents of economically distressed communities (which may include Investment Areas)." "185 Although the statute does not define "primary mission" or "purposefully directed," regulations require CDFIs to demonstrate that a

${ }^{178}$ Lehn Benjamin, Julia Sass Rubin \& Sean Zielenbach, Community Development Financial Institutions: Current Issues and Future Prospects, 26 J. Urban Aff. 177, 185-86 (2004); Pinsky, supra note 174.

179 12 C.F.R. $§ 1805.201($ b)(1) (2019).

${ }^{180}$ Indicia of "economic distress" include (i) "[t]he percentage of the population living in poverty is at least 20 percent"; (ii) "the median family income [is] at or below 80 percent" of the area's median family income or national median family income; and (iii) "[t]he unemployment rate is at least 1.5 times the national average." 12 C.F.R. $\S 1805.201(\mathrm{~b})(3)(\mathrm{ii})(\mathrm{D})$ (2019).

181 12 U.S.C. $\S 4702(16)$ (2018)

182 Id. § 4702(17) (defining "low-income" as not more than eighty percent of the area's median income).

${ }^{183}$ Id. $\S 4702(20)$.

${ }^{184}$ Id. $\$ 4702(5)(A)$. ““[D]evelopment services’ means activities that promote community development and are integral to lending or investment activities ....” Id. § 4702(9).

18512 C.F.R. $§ 1805.201(\mathrm{~b})(1)(2019)$. 
minimum of sixty percent of their financing activities are directed to one or more of their target markets. ${ }^{186}$

CDE certification is very similar, except that it is designed for a broader class of firms beyond financial institutions. $\mathrm{A} C \mathrm{CDE}$ is a domestic corporation or partnership (i.e., a for-profit entity) that is an intermediary vehicle for the provision of loans, investments, or financial counseling in low-income communities. To become certified as a CDE, an organization's primary mission must be to serve low-income communities, ${ }^{187}$ and it must maintain accountability to the residents of such communities. ${ }^{188} \mathrm{CDE}$ status requires that the entity serves "lowincome communities" 189 — which are, in essence, defined in virtually the same way as "investment areas." 190

(2) Subsidy-lock: The certification, on its own, is insufficient as a commitment device because the firm could change its business after it obtains the certification and stop providing services to low-income individuals. This is why the government also resorts to contractual mechanisms and continued monitoring of CDFIs. In order to receive an award, CDFIs must enter into an "assistance agreement" that specifies performance goals negotiated with the CDFI Fund, such as expanding operations into a new investment area and serving a new targeted population. ${ }^{191}$ CDFIs must only use awards and their corresponding matching funds for the eligible activities described in the assistance agreement, ${ }^{192}$ which must include specific lending, investment, and development service objectives. ${ }^{193}$ The CDFI Fund may terminate the

18682 Fed. Reg. 2251 (proposed Jan. 9, 2017); CDFI Fund, Frequently Asked Questions (FAQs): CDFI Investment Area Transition to the American Community Survey 2011-2015 Data 2 (Oct. 1, 2018), https://www.cdfifund.gov/Documents/CDFI\%20Investment\%20Areas\%20potential\%20FAQs\%20FINAL\%20100118.pdf [https://perma.cc/744G-HDC5].

${ }^{187}$ To demonstrate that its primary mission is to serve low-income persons, a CDE must (i) "provide organizational documents evidencing such a mission, and" (ii) certify that at least sixty percent of its activities are directed towards low-income persons. CDFI Fund, New Markets Tax Credit: CDE Certification Question \& Answer 4 (2005), https://www.novoco.com/sites/default/files/atoms/files/cde_q_a_0705.pdf [https://perma.cc/FLT3E5Q5].

18826 U.S.C. $\S 45 \mathrm{D}$ (c) (2018).

${ }^{189} \mathrm{Id}$.

190 Compare id. $\S 45 \mathrm{D}(\mathrm{e})$ (2018) (defining low-income community), with 12 C.F.R. $\S 1805.201$ (b)(3)(ii) (2019) (defining investment area).

19112 U.S.C. $\S 4707(f)(2)(2018)$.

19212 C.F.R. $\$ 1805.302$ (a) (2019).

${ }^{193}$ Id. § 1805.801(b)(4). 
award and bar the CDFI from reapplying for future assistance for failure to meet certain performance goals. ${ }^{194}$

Furthermore, there is a risk that for-profit firms will seek to claim NMTCs for regular, profit-maximizing projects. There are several measures to address this risk. First, the amount of tax credits is limited and is spread out across several years. ${ }^{195}$ Second, the CDE must use substantially all of the cash from the investment to make qualified lowincome community investments, meaning that (i) at least fifty percent of the total gross income of the entity must be derived from active conduct within a low-income community; (ii) a substantial portion of the tangible property of the entity must be within a low-income community; and (iii) a substantial portion of the work performed by employees should be within a low-income community. ${ }^{196}$ Failure to satisfy these requirements will result in the recapture of the tax credits. ${ }^{197}$ Thus, the CDFI Fund has to monitor its subsidies to make sure that they are actually used for their intended purpose.

(3) The terms of the transactions with the beneficiaries: The CDFI regulations themselves do not dictate the terms of the loans with the customers of CDFIs. In fact, the interest rates charged by CDFIs tend to be somewhat higher than those charged by commercial banks, but they are not as high as those charged by payday lenders. ${ }^{198}$ This underscores CDFIs' role in facilitating investments that otherwise would not occur. They do not just provide cheaper versions of existing loans and financial products because reduced interest rates do not necessarily help disadvantaged groups; the high costs of such loans may dissuade banks from providing any financial services to these groups at all. As long as the marginal benefits of loans are higher than their price, and there are no predatory tactics employed by the firms, the loans are welfare-enhancing.

Nonetheless, three mechanisms operate to reduce the costs of CDFIs' financial products. First, although the assistance agreement does not necessarily regulate prices, the CDFI Fund may, and sometimes does,

${ }^{194}$ Id. $\S 1805.802(\mathrm{c})$.

19526 U.S.C. $\$ 45 \mathrm{D}$ (a) (2018).

${ }^{196}$ Id. $\S 45 \mathrm{D}(\mathrm{d})(2)$.

${ }^{197}$ Id. $\S 45 \mathrm{D}(\mathrm{g})$.

198 Bianca Crouse, Is a CDFI Loan Right for My Business? Merchant Maverick (Nov. 18, 2019), https://www.merchantmaverick.com/take-business-loan-cdfi/ [https://perma.cc/46XCLC3Q]. 
require that loans or other products be provided at affordable rates. ${ }^{199}$ Second, many CDFIs are formed as nonprofits or credit unions, and thus their incentives to over-charge or exploit their customers may be weaker. ${ }^{200}$ Third, as an alternative to the nonprofit form, CDFIs may use control mechanisms, such as ownership by a nonprofit foundation. That nonprofit may induce the CDFI to charge lower rates.

$$
* * *
$$

The evidence suggests that the CDFI program generally achieves its goals, such as serving new client populations and geographic markets, developing new services, expanding the scale of services, developing new products, expanding existing lending or investing programs, and improving self-sufficiency ratios over time. ${ }^{201} \mathrm{~A}$ recent empirical study found that CDFI grants increased lending at CDFI-certified credit unions by three percent. ${ }^{202}$ Further, for every dollar awarded, forty-five additional cents are loaned to borrowers in the first year, and up to an additional $\$ 1.60$ is loaned out within three years. ${ }^{203}$ The financial assistance awards have been described as relatively small subsidies that ultimately have large effect. ${ }^{204}$ There are also indications that the program contributes to other external effects, such as job creation, small business development, and neighborhood revitalization. ${ }^{205}$

199 See CDFI Fund, Fact Sheet: New Markets Tax Credit Program (2018), https://www.cdfifund.gov/Documents/NMTC\%20Fact\%20Sheet_Jan2018.pdf [perma.cc/X$83 \mathrm{G}-7 \mathrm{MHX}$ ] (stating that the purpose of the program is to provide affordable financial products and services).

${ }^{200}$ See generally Ryan Bubb \& Alex Kaufman, Consumer Biases and Mutual Ownership, 105 J. Pub. Econ. 39 (2013) (finding that a firm's nonprofit status can prevent it from exploiting consumer biases).

201 CDFI Fund, CDFI Program Award Book (2017), https://www.cdfifund.gov/Documents/FINAL\%202017\%20CDFI\%20Award\%20Book\%20091817_for\%20web.pdf [https://perma.cc/GXN7-VDEA] [hereinafter CDFI Program Award Book]; Michael Swack et al., CDFI Fund, CDFIs Stepping into the Breach: An Impact Evaluation-Summary Report 4-5 (2014), https://www.cdfifund.gov/Documents/CDFIs\%20Stepping\%20into\%20the\%20Breach\%20Impact\%20Evaluation\%20Report.pdf [https://perma.cc/D9D7-ZD4Q].

${ }^{202}$ Kristle Romero Cortés \& Josh Lerner, Bridging the Gap? Government Subsidized Lending and Access to Capital, 2 Rev. Corp. Fin. Stud. 98, 98 (2013).

${ }^{203}$ Id.

${ }^{204}$ See id. at 101 (stating that "the CDFI Funds effects on recipients have been economically significant," despite the fact that the program is of "relatively small size," though positing that the small size may benefit the Fund as it insulates it from political pressures).

${ }^{205}$ Swack et al., supra note 201, at 21-22. 
There are greater concerns with the NMTC program because it focuses on for-profits firms, which arguably would have made investments in low-income communities anyway. ${ }^{206}$ However, evidence suggests that the program facilitates projects in low-income areas, such as real estate rehabilitation and investment in small business, which would not otherwise be made. ${ }^{207}$ More specifically, a recent study finds that community development venture capital funds (CDVCs) - a subset of $\mathrm{CDEs}$ - are more likely to invest in regions and industries with little prior venture activity and that have lower probabilities of exit. Moreover, CDVC investment results in additional VC firms in a region-suggesting that CDEs help resolve the informational asymmetries that standard venture capital firms face when considering investments in low-income communities. ${ }^{208}$

The effectiveness of the CDFI regime bolsters the notion that social enterprises that transact with their beneficiaries should serve as the basis for a social enterprise law. The CDFI Fund is not the only agency that relies on its certifications; foundations also consider them in making PRIs, and a significant proportion of CDFIs' financing comes from PRIs. ${ }^{209}$ In fact, commentators recommend mitigating the potential financial and reputational risk of PRIs by investing in CDFIs. ${ }^{210}$ CDFIs may also help foundations leverage relatively small PRIs by aggregating investors and investees. ${ }^{211}$ Unlike the PRI criteria, the CDFI criteria are

\footnotetext{
${ }^{206}$ Julia Sass Rubin \& Gregory M. Stankiewicz, The New Markets Tax Credit Program: A Midcourse Assessment, 1 Community Dev. Inv. Rev. 1, 5-7 (2005).

${ }^{207}$ Martin D. Abravanel et al., New Markets Tax Credit (NMTC) Program Evaluation: Final Report vii (2013), https://www.urban.org/research/publication/new-markets-tax-credit-nmtcprogram-evaluation/view/full_report [https://perma.cc/N4WY-LY7N]; Elise Balboni \& Christina Travers, CDFIs \& Impact Investing: An Industry Review 6 (2017), https://www.newyorkfed.org/medialibrary/media/outreach-and-education/2017/CDFIsImpact-Investing.pdf [https://perma.cc/8JKM-NLCL].

${ }^{208}$ Anna Kovner \& Josh Lerner, Doing Well by Doing Good? Community Development Venture Capital, 24 J. Econ. \& Mgmt. Strategy 643, 644, 660-61 (2015).

209 See Rosalie Sheehy Cates \& Chris Larson, Ford Found., Connecting CDFIs to the Socially Responsible Investor Community 4 tbl.2 (2010), https://www.mycdfi.cdfifund.gov/what_we_do/resources/Connecting\%20CDFIs $\% 20$ to $\% 20$ the $\% 20$ Socially $\% 20$ Responsible $\%$ 20Investor\%20Commun.pdf [https://perma.cc/9A2K-6GAM] (finding that foundations were the source of debt capital for six to fourteen percent of business-funding CDFIs and two to twenty-four percent of housing-funding CDFIs).

${ }^{210}$ See, e.g., James P. Joseph \& Andras Kosaras, New Strategies for Leveraging Foundation Assets, 20 Tax'n Exempts 22, 27 (2008); PRI Makers Network, Frequently Asked Questions About Program-Related Investments 2 (Feb. 2011), https://www.mycdfi.cdfifund.gov/what_we_do/resources/Feb\%202011\%20PRI\%20Primer.pdf [https://perma.cc/8JX7-JEX5].

211 Joseph \& Kosaras, supra note 210, at 27.
} 
specific and help mitigate uncertainty as to whether an investment qualifies as a PRI. The certification also appears to facilitate subsidized investments from private investors, who rely on the CDFI Fund's expertise and information in vetting investees. Thus, the basic elements of the CDFI program are a promising basis for developing a broader certification.

Nonetheless, some missing elements in the CDFI program make it an imperfect commitment device for private investors who seek social impact. The program is ultimately intended to assure the government that its subsidies are used effectively. The government is well-positioned to enter into and monitor contracts with the subsidized firms. However, any certified firm can simply renege on the certification and stop providing services to low-income people, expropriating any altruistic investments. This is likely why many CDFIs form as nonprofits or credit unions that are subject to a distribution constraint. The distribution constraint serves as a commitment not to change the firm's mission by renouncing the certification. For-profit firms need to resort to contractual and control mechanisms. ${ }^{212}$ This is likely the reason why investments in CDFIs do not automatically qualify as PRIs; rather, the certification is only one factor in satisfying foundations' obligations to verify the social mission of their investees. Moreover, the certification does not, on its own, specify what level of assistance the beneficiaries need: are they marginally vulnerable or terminally poor? Investors need this information to decide how much subsidy to provide to the firm, and the costs of diligence may be preclusive for most of them.

\section{B. Design Flaws in Other Corporate Subsidies}

When evaluating certification mechanisms that verify firms' transactional relationships with their beneficiaries, it is important to emphasize that the CDFI regime is not the only such certification system in the U.S.; other such systems couple with subsidy programs and seek to achieve similar purposes. Unlike the CDFI regime, which seems to work

${ }^{212}$ For example, the Carver Bank, a publicly traded CDFI, is structured such that it would be largely impossible for an outside investor to acquire control over the company and rescind the firm's social mission to serve the community. Among other provisions, no investor may acquire more than ten percent of the shares, and in considering a takeover bid, the board may consider the effects of the bid on the communities in which the company is located. See Carver Bancorp Inc., Form S-4EF 167, 170 (June 7, 1996), https://www.sec.gov/Archives/edgar/data/1016178/0000950123-96-002932.txt [https://perma.cc/BLK7-PBFU]. 
remarkably well, other programs seem to be less effective. The reason is not the basic concept of subsidizing firms with a commitment to transacting with their beneficiaries, but rather that the designs of the relevant programs are flawed.

For instance, credit unions, a form of customer-owned financial institution, initially emerged to facilitate access to credit for low-income individuals. ${ }^{213}$ Credit unions benefit from government subsidies in the form of federal ${ }^{214}$ and state tax exemptions..$^{215}$ To qualify as credit unions, financial institutions must serve only their members, who also own and control them as cooperatives. The membership of a credit union must comprise an identifiable group of people with a "common bond." 216 Historically, the common bond served to mitigate information asymmetries with respect to borrowers' abilities in low-income communities. The underlying rationale was that "[p]eople working, or associating, or living together in compact communities knew each other and were usually aware of a colleague's ability or disposition to repay a loan." 217

However, the role of credit unions has fundamentally changed due to policies that liberalized the "common bond" requirement to include occupational bonds that include members employed in industries that have relatively high-wage jobs. ${ }^{218}$ Consequently, credit unions are no longer about community development; rather, they are an alternative for middle-class investment. Indeed, there is evidence that credit unions serve a slightly lower proportion of low-income households than do banks. ${ }^{219}$ Accordingly, the customers of credit unions do not appear to be disadvantaged as compared to the customers of commercial banks. In fact, the main effect of the subsidy is seemingly to enable credit unions to grow

213 U.S. Gov't Accountability Office, GAO-06-220T, Financial Institutions: Issues Regarding the Tax-Exempt Status of Credit Unions 2 (2005).

21412 U.S.C. $\$ 1768$ (2018).

215 Jeremy D. Franklin, Credit Unions: Who Should Be Able To Serve the Underserved?, 11 N.C. Banking Inst. 237, 240 (2007).

21612 U.S.C. $\$ 1759$ (2018).

${ }^{217}$ Franklin, supra note 215, at 239 (quoting Credit Union Membership Rules: Before the Subcommm. on Fin. Insts. \& Consumer Credit of the H. Comm. on Banking \& Fin. Servs. (testimony of Norman E. D'Amours, Chairman, Nat'l Credit Union Admin.) (1997), 1997 WL 82221).

${ }^{218}$ John Tatom, Competitive Advantage: A Study of the Federal Tax Exemption for Credit Unions, Tax Found. 2, 6 (2005).

${ }^{219}$ GAO-06-220T, supra note 213, at 22. 
faster than other institutions. ${ }^{220}$ This suggests that subsidies are used for empire building ${ }^{221}$ rather than increasing access to capital. ${ }^{222}$

Another ineffective subsidy program is the Work Opportunity Tax Credit (WOTC). The WOTC program offers subsidies to for-profit firms that employ a wide range of disadvantaged workers, including recipients of welfare payments, workers in designated empowerment zones, and exfelons. ${ }^{223}$ The tax credits under the WOTC are allocated on a periodic basis per worker employed at the firm, as long as the worker is employed for a minimum period of time. ${ }^{224}$

There are two critical problems with the program. First, it has suffered from a windfall problem due to a practice that allowed firms to apply for certification of already-hired workers. ${ }^{225}$ Despite reforms to the application process, the evidence, albeit partial, suggests that WOTC credits are being claimed for hiring that would have been done anyway. ${ }^{226}$ This suggests that the subsidies increase companies' earnings without creating any benefit.

220 James Disalvo \& Ryan Johnston, Fed. Reserve Bank of Phila. Research Dep't, Credit Unions' Expanding Footprint 17, 18-22 (2017), https://www.philadelphiafed.org//media/research-and-data/publications/banking-trends/2017/bt-credit_unions.pdf?la=en [https://perma.cc/8W3L-YDD6]. There is also evidence that CEO pay at credit unions is higher than CEOs at other banks. Peter Strozniak, Average Credit Union CEO Pay Now \$256,339: CUES Survey, Credit Union Times (Aug. 5, 2013), http://www.cutimes.com/2013/08/05/average-credit-union-ceo-pay-now-256339-cues-surve [https://perma.cc/P835$7 \mathrm{~S} 2 \mathrm{H}]$.

221 The interest rates charged by credit unions are only slightly lower than those of commercial banks. Tatom, supra note 218 , at 15-16.

222 To address this deficiency, recent reforms introduced a certification for credit unions as low-income (LI CU). Similar to a CDFI, an LI CU is defined as a credit union that serves predominantly low-income members. 12 C.F.R. $\$ 701.34$ (2019). The regulation also implies that regulatory requirements may be waived for LI CUs, and they may apply for grants and low-interest loans from NCUA. However, this certification seems superfluous because credit unions can be certified as CDFIs.

22326 U.S.C. $\$ 51(\mathrm{~d})(2018)$.

${ }^{224}$ Benjamin Collins \& Sarah A. Donovan, Cong. Research Serv., R43729, The Work Opportunity Tax Credit 1 (2018).

${ }^{225}$ Anne L. Alstott, Work vs. Freedom: A Liberal Challenge to Employment Subsidies, 108 Yale L.J. 967, 1034-35 (1999); Timothy J. Bartik, Jobs for the Poor: Can Labor Demand Policies Help? 204, 224-29 (2001).

${ }^{226}$ Christine Scott, Cong. Research Serv., RL30089, The Work Opportunity Tax Credit (WOTC) 12 (2013). There is also a risk of displacement, firing employees and hiring disadvantaged workers, and churning (firing and rehiring to maximize subsidy payments). However, there seems to be little evidence of this in practice, perhaps because the paperwork associated with these programs seems to be burdensome. U.S. Gov't Accountability Office, GAO-01-329, Work Opportunity Tax Credit: Employers Do Not Appear To Dismiss Employees To Increase Tax Credits 13 (2001). 
Second, there is no requirement that a certain percentage of the employees be low-income persons, and thus firms need not have a significant scale of business that truly depends on disadvantaged workers. In fact, one government study found that most of the tax credits are claimed by very large companies, most of which have less than one hundred WOTC hires. ${ }^{227}$ Moreover, most of these workers are employed in industries with characteristically high turnover (such as hotels and restaurants), where the workers are unlikely to hold a job for long periods. Accordingly, these firms have very limited incentives to invest in developing their workers' skills through training and other subsidies, such as housing and education. ${ }^{228}$ Further, employers estimate that the perworker credit offsets less than half the costs of recruiting, hiring, and training credit-eligible employees. ${ }^{22}$ This indicates that there are high fixed costs to employing and training truly disadvantaged workers, and that a large, fixed subsidy to fund the fixed costs associated with creating a business model that specializes in disadvantaged workers would be preferable.

\section{Alternatives to Certification: Mandatory Requirements To Transact with Beneficiaries}

As an alternative to voluntary certification, why not require all firms to serve disadvantaged groups? In fact, U.S. law does exactly that under the Community Reinvestment Act (CRA), which requires banks to make loans to borrowers in low-income communities in areas in which the

${ }^{227}$ GAO-01-329, supra note 226, at 24 tbl.4, indicates that 775 out of 975 WOTC employers in California, and 610 out of 863 in Texas, had less than 100 WOTC hires. While the report also noted that a small number (three percent) of participating employers accounted for the vast majority (eighty-three percent) of the total WOTC hires, this seems to mainly reflect specializing in carrying out the application process for credits. Id. at 2.

228 The GAO states that employers do report making some changes to their training programs to reflect the needs of WOTC hires. Id. at 17 . However, these changes seem to be trivial. Most importantly, as employers also claim not to have changed their hiring criteria in terms of skill levels required, these WOTC workers likely do not need special training as they already have sufficient capabilities. See Peter Cappelli, Assessing the Effect of the Work Opportunity Tax Credit 26 (2011), https://www.adp.com/ /media/Reference\%20PDFs/Cappelli_Study_2011.ashx [https:// perma.cc/LY6K-45VL] (explaining that "[a] set of case studies conducted for the US Department of Labor in 2001 concluded that while employers liked the program and the WOTC-certified employees they hired seemed to do about as well as other candidates, the employers would have hired those employees in any case and that the subsidies played little role in the hiring decisions").

${ }^{229}$ GAO-01-329, supra note 226 , at 13 . 
banks have branches. ${ }^{230}$ The CRA has been criticized by some commentators who argue that commercial banks may not be effective in providing financial services to the poor, and that the costs imposed on banks are too high. ${ }^{231}$ This is likely because commercial banks' profits do not depend on disadvantaged borrowers, and they have not developed expertise in providing services to low-income clients.

However, as discussed above, CDFIs generally enjoy an informational advantage over other commercial banks with respect to low-income borrowers, and the CRA recognizes these advantages by allowing banks to fulfill their CRA obligations by lending to, and investing in, CDFIs. ${ }^{232}$ Banks have done so in "record numbers." 233 Other than complying with their CRA obligations, banks seek to benefit from CDFIs' expertise in the target markets; this expertise may help banks penetrate low-income markets and decrease the risk of banks' investments. ${ }^{234}$ Accordingly, the CRA is not a good substitute for CDFIs. In fact, without CDFIs, the CRA could create a major source of losses for commercial banks. Although this is beyond the scope of this Article's inquiry, the CRA appears to work as a complement to the CDFI program, rather than a substitute.

\section{THE DESIGN OF A SOCIAL ENTERPRISE LEGAL ForM}

This Part will discuss in greater detail the design of the social enterprise legal form. The basic proposal is to introduce a social enterprise legal form, which will be governed by a newly constituted government agency that will certify firms as social enterprises. The certification would be awarded to firms committed to transacting with disadvantaged groups. A social enterprise will be required to obtain and maintain the certification, unless a qualified majority of its shareholders decides to terminate the social enterprise status of the firm. The names of certified firms will

\footnotetext{
23012 U.S.C. $\$ 2903$ (2018).

${ }^{231}$ See generally Michael Klausner, Market Failure and Community Investment: A MarketOriented Alternative to the Community Reinvestment Act, 143 U. Pa. L. Rev. 1561 (1995) (arguing that the CRA is inefficient and ineffective); Jonathan R. Macey \& Geoffrey P. Miller, The Community Reinvestment Act: An Economic Analysis, 79 Va. L. Rev. 291 (1993) (criticizing the effects of the CRA on several grounds). But cf. Michael S. Barr, Credit Where It Counts: The Community Reinvestment Act and Its Critics, 80 N.Y.U. L. Rev. 513, 513 (2005) (arguing that the CRA has "enhanced access to credit for low-income, moderateincome, and minority borrowers at relatively low cost").

${ }^{232}$ Kovner \& Lerner, supra note 208 , at 646-47.

${ }^{233}$ Barr, supra note 231, at 606.

${ }^{234}$ Id.
} 
include "SE" as a suffix. Accordingly, when investors buy shares in a social enterprise or when consumers buy their products, they will have notice that the firm transacts with a class of beneficiaries. The suffix can be further tailored to specify the type of disadvantaged group that the firm transacts with, for example, "SE workers" or "SE consumers." Each firm can also attach specified marks to its products to signal the social mission of the firm to consumers. In the following Sections, I further discuss the key elements of the social enterprise legal form.

However, there remains one additional question: Why a single legal form and not multiple government certifications for low-income workers, borrowers, investees, etc.? There are three main advantages to a single legal form. First, it can provide useful signaling and branding advantages for social enterprises that serve social missions. In fact, this seems to be one of the main motivations for firms to adopt the existing legal hybrid forms, such as the benefit corporation. Second, a legal form is a more natural device for ensuring that the firm remains committed to being a social enterprise, and therefore the subsidy is locked into the mission. The legal hybrid forms have devices that impede conversion into a conventional for-profit (thereby preventing managers from expropriating subsidies the organization has received). In contrast, without substantial monitoring by the CDFI Fund, a certified CDFI can renege relatively easily on the mission of the firm. Third, a single legal regime for social enterprises also facilitates a holistic approach to development rather than assigning different development missions to different government agencies (as is the case under the current approach). A single agency will be better equipped to regulate and monitor social enterprises than separate agencies with narrower interests and perspectives.

\section{A. Identifying and Differentiating Among Beneficiaries}

Creating a new legal form for social enterprises requires good proxies for the abilities of beneficiaries and for the market failures that prevent conventional commercial firms from transacting with them. As under the CDFI regime, these proxies can be laid out in regulations so they are sufficiently flexible to adapt to changing economic conditions. There are several proxies that are good candidates. For example, the CDFI program uses proxies such as the average income or employment rate in a given area. ${ }^{235}$ Similarly, privately created MFIs and WISEs typically focus on

235 See supra Section III.A. 
specific regions where a significant portion of the population is lowincome or suffers from systemic unemployment. ${ }^{236}$ Other standard proxies used by European WISEs include past criminal record and disabilities and behavioral disorders. ${ }^{237}$

However, criteria such as size or organizational form (for example, whether the firm is a cooperative) may distort the identification of disadvantaged groups. For example, the Fair Trade certification is available only to cooperatives formed by small producers, defined as farmers that mainly rely on family workers as opposed to hired labor. ${ }^{238}$ However, a cooperative of wealthy farmers that rely on family labor may be well-positioned to sell their produce to large multi-nationals. Alternatively, if a large firm establishes a business corporation and employs farmers in an impoverished area, there is little reason to deny it the Fair Trade mark. ${ }^{239}$ Accordingly, measures of regional income and unemployment are likely better metrics for identifying the poorest of the farmers as well as other beneficiaries.

The proposal will also differentiate among beneficiaries that belong to the same class. Some workers are harder to employ than others. A social enterprise that transacts with beneficiaries with greater needs or lower abilities will naturally need larger subsidies, and the enterprise needs to signal these needs to subsidy providers. Such differentiation can be accomplished by simply applying different labels for different levels of need. For example, in addition to labeling a social enterprise as, say, "SE Workers," the mark would further communicate the level of poverty or need within that class. For instance, "SE Workers 3" could refer to workers who belong to a community where the unemployment rate is three times the national average, whereas "SE Workers 2" would correspond to a community where the unemployment rate is twice the national average. The same would apply to other types of beneficiaries. The number of sub-classes should generally remain relatively small to make the classifications administratively feasible and to not confuse consumers and investors.

\footnotetext{
${ }^{236}$ See, e.g., Eldar, supra note 10, at 114 (discussing the Greyston Bakery).

${ }^{237}$ See supra Section II.C.

${ }^{238}$ Eldar, supra note 10, at 152-53; Colleen Haight, The Problem with Fair Trade Coffee, Stan. Soc. Innovation Rev., 77 (Summer 2011), https://ssir.org/pdf/2011SU_CaseStudy_Haight.pdf [https://perma.cc/GV7H-CFDP].

${ }^{239}$ Haight, supra note 238 , at 77 .
} 
Finally, it is noteworthy that many of the beneficiaries of social enterprises are located abroad in developing countries. A federal agency might have insufficient expertise to lay out criteria of need for disadvantaged groups in developing countries. Therefore, this task may be conducted in collaboration with other government agencies that have such expertise, specifically the U.S. development agencies, such as USAID. In addition, it may be possible to outsource this task to a private nonprofit, like the Fair Labelling Organization, subject to certain restrictions.

\section{B. The Scale of the Social Enterprise}

There is also a concern that the certified entity would not be financially dependent on its beneficiaries, and therefore the firm would have limited incentives to tailor the subsidies to their needs. Moreover, the extent to which a business serves disadvantaged patrons is a strong factor in determining whether investment in that business qualifies as a PRI. ${ }^{240}$ It is therefore not surprising that WISE legal forms require that at least thirty percent of the workers employed by the entity belong to a disadvantaged class. ${ }^{241}$ Likewise, to be certified as a CDFI, a financial institution must direct sixty percent of its financing activity to low-income persons; to qualify as a CDE, it must focus at least sixty percent of its activities on low-income communities or people. ${ }^{242}$

Importantly, different thresholds may be needed for social enterprises that transact with different beneficiaries. It is possible, for example, that a thirty percent threshold is restrictive for WISEs; it is difficult to imagine a large firm where a significant number of workers suffer from serious behavioral problems. In contrast, sourcing coffee from farmers in developing countries seems more financially feasible, mainly because, with some training, many of these farmers are likely to enhance their abilities. There are many examples of FTSEs that source all their products from small producers. ${ }^{243}$ Accordingly, qualifying thresholds for these firms may be higher.

\footnotetext{
${ }^{240}$ See supra Subsection I.B.2.

${ }^{241}$ See supra Section II.C.

${ }^{242}$ See supra notes $186-187$ and accompanying text.

${ }^{243}$ See e.g., Eldar, supra note 10, at 111-13. Even Starbucks, for example, had already sourced about eight percent of its coffee from Fair Trade certified producers in 2012. Starbucks, 2012 Global Responsibility Report: Year in Review 4 (2012),
} 
Finally, it might be prudent to relax threshold requirements for very large firms. These firms might have a sufficient economic incentive to employ subsidies effectively-even if a smaller percentage of their patrons (e.g., workers) are disadvantaged - simply because the economic stake will be large. Moreover, percentage requirements might impose excessive burdens on very large firms; for example, it could be a significant undertaking for a large firm with billions of dollars in sales to draw twenty percent of its workers from disadvantaged groups. Accordingly, there is scope for introducing percentage requirements that depend on the size of the firm. For example, thirty percent of workers could be required to be disadvantaged for small firms, twenty percent for medium-sized firms, and ten percent for large firms. A firm with 1000 workers (i.e., a medium-sized firm) could be considered a social enterprise if 200 of its workers are disadvantaged, but for a ten-person firm, a thirty percent requirement makes more sense (three qualifying workers rather than two).

\section{Subsidy-Lock: Terminating the Social Enterprise Certification}

A social enterprise form must also ensure that those who control the firm will not be able to renounce the certification and expropriate the subsidies they receive. The most plausible approach is to require a qualified majority of the shareholders to pass a resolution to renounce the certification, similar to benefit corporation statutes. Alternate approaches, such as requiring social enterprises to be employee-owned cooperatives or imposing constraints on distribution, seem too restrictive in this context because (i) they may create significant hurdles to attracting much-needed capital and (ii) they may weaken the incentives of entrepreneurs to form social enterprises. ${ }^{244}$ Most benefit corporation statutes require a twothirds majority. ${ }^{245}$ This requirement is intended to discourage the conversion of social enterprises into conventional for-profits.

The main justification for a conversion arises in circumstances where the mission of the firm is accomplished such that the beneficiaries are no longer disadvantaged. In these circumstances, the firm would have the following options: (i) transact with a different group of beneficiaries that

https://globalassets.starbucks.com/assets/581d72979ef0486682a5190eca573fef.pdf [https://perma.cc/XLR7-8JRL].

${ }^{244}$ Eldar, supra note 14, at 31, 35.

${ }^{245}$ Model Benefit Corp. Legislation $\S \S 104,105$ (2017). 
qualify as disadvantaged in order to maintain the certification; (ii) dissolve and terminate operations; or (iii) obtain the required majority to terminate the social enterprise status, and continue to operate as a conventional for-profit. The final option in fact tracks the evolution of many social enterprises, such as MFIs, that eventually become standard commercial firms. ${ }^{246}$

\section{Fiduciary Duties}

Unlike many legal hybrid forms, such as the benefit corporation, there is little reason for the social enterprise legal form to adopt a fiduciary standard different from standard corporations, with one caveat: directors would have a duty to maintain the social enterprise certification. Thus, subject to the requirement to maintain the certification, directors should generally seek to maximize firms' profits. The managers of social enterprises have incentives to use subsidies effectively even if - and in fact because - the managers are motivated to make profits. If managers were not trying to maximize firm revenues, they would have few incentives to measure their beneficiaries' abilities and tailor subsidies to their needs. If allocated wide discretion to pursue social goals, managers might simply abuse it and pursue policies that have limited or no social value. $^{247}$

\section{E. Public Markets for Social Enterprises}

A major obstacle to facilitating public markets for social enterprises is the cost of commitment devices for public investors. ${ }^{248}$ There have been some attempts in countries such as the U.K. and Canada to create special stock exchanges for firms that pursue blended profit and social missions. ${ }^{249}$ However, these attempts have been inconsequential because they are based on the same unsuccessful mechanisms used by the U.S. hybrid legal forms, such as disclosure, fiduciary duties, and comprehensive third-party standards that are difficult to measure. ${ }^{250} \mathrm{In}$ contrast, a social enterprise legal form would certify to all investors that

${ }^{246}$ Eldar, supra note 14, at 26-28.

${ }^{247}$ See supra Section II.A.

${ }^{248}$ See supra Subsection I.B.1.

249 Bandini Chhichhia, The Rise of Social Stock Exchanges, Stan. Soc. Innovation Rev. (Jan. 8, 2015), https://ssir.org/articles/entry/the_rise_of_social_stock_exchanges [https://perma.cc/H82E-KDJC].

${ }^{250}$ See Dadush, supra note 46, at 176-77, 195-96, 218. 
the firm is committed to transacting with a specific disadvantaged group, and would communicate the level of need of that group. Accordingly, investors would need to exert minimal effort in verifying the social mission of the firm. Moreover, to the extent that social enterprises would compete for investments, altruistic investors would not pay subsidies in excess of what is necessary for firms to carry out their social missions. Social enterprises that demand excess subsidies would be competed out by others that do not. In such a system, there would be little need for a specialized stock exchange to evaluate and certify firms, and social enterprises could be listed on major stock exchanges.

\section{F. A Federal Agency for Certifying Social Enterprises}

At present, legal hybrid forms in the U.S. are adopted by states. Although state competition in the market for corporate law may be viewed as advantageous, ${ }^{251}$ there is little reason to believe that is the case for hybrid legal forms. In fact, states' creation of hybrid legal forms was recently labeled "a race to the bottom," suggesting that state legislatures are passing these statutes with an eye toward gaining federal tax benefits for local firms in the future. ${ }^{252}$ Social enterprises involve development issues that affect all states and require coordinated federal policy. There is little reason in this context to introduce different regimes for different states, particularly because these firms might (as discussed below) need government subsidies, in addition to private ones. This is the approach of the CDFI regime, where a single federal CDFI Fund certifies CDFIs and $\mathrm{CDEs}^{253}$

Accordingly, the optimal approach is to establish a special social enterprise agency akin to the CDFI Fund. The agency would be responsible for certifying social enterprises and monitoring their compliance with the law, particularly the commitment to transacting with a class of disadvantaged beneficiaries. If a social enterprise fails these requirements, it may lose its certification. There is also scope for introducing a procedure whereby subsidy-providers can file a complaint to the regulator asking it to compel a company to fulfill its duties under

\footnotetext{
${ }^{251}$ Roberta Romano, The Genius of American Corporate Law 15-22 (1993); Ofer Eldar \& Lorenzo Magnolfi, Regulatory Competition and the Market for Corporate Law, Am. Econ. J. 1-2 (forthcoming May 2020), https://papers.ssrn.com/abstract=2685969 [https://perma.cc/3NG8-P64S].

${ }^{252}$ Galle, supra note 44, at 2041.

${ }^{253}$ See supra Section III.A.
} 
the certification. Thus, ethically motivated shareholders and consumers who want to ensure that social enterprises truly help disadvantaged patrons will assist the regulator in monitoring the certification. This would be a better monitoring mechanism than a derivate lawsuit pursuant to the benefit corporation statute, since small shareholders are unlikely to be able to bear the costs of such litigation. ${ }^{254}$ The social enterprise agency would be better suited to enforce the requirements.

Instead of creating a separate agency for each type of social enterprise that serves a different class of patrons (e.g., the CDFI Fund with respect to low-income borrowers), there are three main reasons for establishing a single agency with responsibility for all social enterprises. First, such an agency could develop a holistic approach to development. ${ }^{255}$ Development issues tend to be integrated. ${ }^{256}$ Providing access to capital may do little to increase income if businesses have few good projects. An opportunity to work might improve families' income, but it will not improve education if there are no good schools. Essential products and services can improve productivity, but not if there are no employment opportunities. A central social enterprise regulator could develop expertise in the links among these issues, which have so far been largely elusive in development studies. Second, this agency could also be influential in setting some of the criteria for certifying social enterprises, including the relevant classes and sub-classes of beneficiaries. These criteria, such as average income and disability, may be related. These criteria may require change over time, and hence they are better set in regulations than statutes. ${ }^{257}$ Third, as mentioned above, one centralized

\footnotetext{
${ }^{254}$ See supra Section III.A.

${ }^{255}$ Francesca Froy \& Sylvain Giguere, OECD, Breaking Out of Policy Silos: Doing More with Less 9 (2010), https://read.oecd-ilibrary.org/urban-rural-and-regional-development/breaking-out-of-policy-silos_9789264094987-en\#page2 [https://perma.cc/GB48-VY2A]

(stating that many development issues "require a holistic approach to be resolved," rather than piecemeal implementation by different agencies).

256 See, e.g., OECD, Effective Local Strategies To Boost Quality Job Creation, Employment, and Participation 7 (2014), https://www.oecd.org/els/emp/OECD-LEED-Localstrategies-for-employment-G20.pdf [https://perma.cc/EMH4-SLAP] ("Labour market policy alone cannot tackle such issues as youth unemployment, the exclusion of ethnic minorities or the informal economy. Issues of transportation, child care, health care, discrimination, housing, training of employers, and lowering barriers to entrepreneurship also need to be considered.").

${ }^{257}$ This is similar to how the CDFI regulation sets the criteria for what counts as "investment area" or "targeted population." See supra Section III.A.
} 
certification agency could help social enterprises in better marketing and branding their roles to both consumers and investors.

\section{G. Mitigating Exploitation: Setting Minimum Terms Versus Constraining Distribution}

It is generally debatable whether the terms of a social enterprise's transactions with its beneficiaries should be regulated. On one hand, it seems natural to expect social enterprises to act fairly towards their beneficiaries, and most of them do. But whether social enterprises should be subjected to standards that go beyond those required to mitigate exploitation under existing laws and regulations is open to dispute. ${ }^{258} \mathrm{At}$ least in the U.S., disadvantaged groups benefit from standard laws that protect workers and consumers against abuse. CDFIs and CDEs are not required to offer favorable terms to their beneficiaries. U.S. WISEs may pay disadvantaged workers less than what commercial firms pay their workers. ${ }^{259}$ However, the workers get a wage above the minimum wage. ${ }^{260}$ More importantly, for social enterprises to make profits, they must provide their beneficiaries with subsidies that will help them develop, whether it is through training or provision of basic needs, such as housing. Requiring a WISE, such as a bakery, to provide higher wages would be counterproductive if it would essentially cause it to lay off workers to remain financially viable.

Regulating the terms of transactions with the beneficiaries may make more sense when background regulation is grossly inadequate, as is often the case in developing countries. It would be undesirable to certify firms as social enterprises while letting them exploit their beneficiaries. Exploitation is a genuine risk because, by definition, social enterprises arise in circumstances where commercial firms are not likely to transact with disadvantaged groups. Without competition, social enterprises may achieve a monopolist or monopsonist position vis-à-vis their beneficiaries, and therefore, if left unregulated, they may act exploitatively.

There are two strategies to address this problem: (i) setting minimum terms and (ii) imposing a mandatory constraint on distribution. Further

\footnotetext{
${ }^{258}$ See supra Section II.C.

${ }^{259}$ For an example, see Eldar, supra note 10 (discussing the Greyston Bakery).

${ }^{260}$ Kate Cooney, Examining the Labor Market Presence of WISEs in the United States, 3rd EMES Int'l Res. Conf. on Soc. Enterprise 8 (2011), https://emes.net/content/uploads/publications/ECSP-R11-16_Cooney.pdf [https://perma.cc/YZG6-BP4Y].
} 
research is necessary to determine which strategy is more desirable in specific circumstances. Broadly speaking, the first approach may be desirable when it is possible to standardize certain minimum requirements. For example, the Fair Trade standards give certain products a floor price, which is periodically adjusted based on commodity exchange prices. ${ }^{261}$ The main advantage of the floor price is that it gives farmers some security, which allows them to invest in the quality of their crops. ${ }^{262}$ The floor price is equivalent to minimum wage regulations and social security benefits, which are not available to farmers in developing countries. Likewise, one might require social enterprises that employ disadvantaged workers in countries that lack adequate labor laws to follow labor standards with respect to minimum wages and labor conditions. ${ }^{263}$

Setting minimum standards for investments in disadvantaged communities may be more difficult. For example, for-profit MFIs that operate in unregulated environments tend to charge high interest rates to low-income borrowers. ${ }^{264}$ While high interest rates are not necessarily exploitative, ${ }^{265}$ there is evidence that MFIs use predatory pricing tactics, including extremely high fees and penalties. ${ }^{266}$ Interest rate caps may arguably address this problem. However, unlike coffee prices, which are based on commodity trades in global exchanges, it may be difficult to standardize other prices, such as lending rates on small loans. Accordingly, setting minimum prices too rigidly could be counterproductive because it could actually leave disadvantaged groups without any assistance if these MFIs simply dissolve or move to other markets.

${ }^{261}$ Fair Trade USA Glossary 10 (2019), https://www.fairtradecertified.org/sites/default/files/filemanager/documents/Glossary/STD_POL_Glossary_EN_1.2.0.pdf [perma.cc/X93QFMPG].

${ }^{262}$ Eldar, supra note 10, at 142-43.

${ }^{263}$ See, e.g., Int'l Labour Org., Minimum Wage Policy Guide 14 (2016), https://www.ilo. org/wcmsp5/groups/public/---ed_protect/---protrav/---travail/documents/publication/wcms_508566.pdf [https://perma.cc/UW5D-YD2S] (recommending setting and complying with minimum wage standards).

${ }^{264}$ Moh'd Al-Azzam \& Christopher Parmeter, Competition and Microcredit Interest Rates: International Evidence, Empirical Econ. (Sept. 3, 2019), https://link.springer.com/content/pdf/10.1007/s00181-019-01766-6.pdf [https://perma.cc/TAQ2-WQ3T].

265 Michael Chu, Commercial Returns at the Base of the Pyramid, Innovations, Winter/Spring 2007, at 127-29 (finding small loans to yield high returns on capital and be advantageous for borrowers despite high interest rates).

${ }^{266}$ See supra notes $246-47$ and accompanying text. 
When standardizing minimum terms is not feasible, social enterprises could adopt a constraint on distribution. As discussed above, this is likely to mitigate the incentives of the organization to exploit its customers and workers. ${ }^{267}$ This requirement may be advisable particularly when the beneficiaries are especially vulnerable - as they would be when the level of need is the highest (for example, when the social enterprise is certified as "SE Workers 3"). To the extent that investors are already prepared to provide subsidies in the form of lower returns, the constraint on distribution would not discourage investment. The goal would be to prevent situations where owners take out extremely high returns while the borrower-beneficiaries have to pay extremely high interest rates. On the other hand, a constraint on distribution might discourage social enterprises that rely on subsidies from consumers, like fair trade firms.

Finally, the proposed legal form may address the problem of exploitation by encouraging greater competition among social enterprises. For example, competition among MFIs has been useful in reducing interest rates charged to low-income borrowers. ${ }^{268}$ To the extent that this proposal enhances competition and reduces exploitation, it is possible that protections against exploitation might be less necessary.

\section{H. Other Metrics for Social Impact}

This proposal focuses exclusively on development missions and enabling low-income people to transact with commercial firms. What about other vital social missions? In particular, what about the environment? Despite the desirability of other social goals, it does not make sense to require firms that adopt the social enterprise legal form to pursue these missions. There are several reasons for this. First, environmental standards may undermine the goals of social enterprises. For example, why require poor farmers in developing countries to adopt environmental standards that even wealthier farmers in developed countries fail to follow? Second, not every environmental standard is relevant for every firm. A clothing firm may wish to communicate that its clothing is made without hazardous materials, whereas a car company

\footnotetext{
${ }^{267}$ For a model that suggests that constraints on distribution should focus primarily on large distributions, see Albert H. Choi, Nonprofit Status and Relational Sanctions: Commitment to Quality Through Repeat Interactions and Organizational Choice, 58 J.L. \& Econ. 969, 971 (2015).

${ }^{268}$ Chu, supra note 265, at 140-41 (discussing Bolivia as an example of a country where interest rates decreased due to competition).
} 
may wish to lower its carbon emissions. As discussed above, there is no way to accurately measure these benefits under a unified, comprehensive standard. ${ }^{269}$ Third, it is not clear that the government is well equipped to create environmental standards for all firms. Whereas the government may be well positioned to identify low-income populations, private certifiers may have better technological expertise and industry knowledge to evaluate the costs and benefits of different environmental standards.

\section{The Design of GovernMEnt Subsidies}

Much of the motivation for introducing legal hybrid forms in the U.S. was to create a legal form that would benefit from tax advantages. ${ }^{270}$ However, a government subsidy for social enterprises may not be necessary. This is because the legal form is designed to attract subsidies from investors and consumers; to the extent that it already attracts sufficient amounts, there is little need for additional government subsidies. The general popularity of firms that combine profit and mission, manifested in the consistent growth of socially responsible investing firms and Fair Trade products, suggests that a social enterprise form could be immensely successful in attracting subsidies.

Nonetheless, some government subsidies may be needed. Social enterprises that commit to transacting with beneficiaries with very low abilities are likely to face difficulties in attracting seed capital and funding start-up costs. The main candidate for contributing such funds are subsidized investments by foundations through PRIs. ${ }^{271}$ Because PRIs are not subject to capital gains tax, there is some government subsidy embedded in such investments. ${ }^{272}$

\footnotetext{
${ }^{269}$ See supra note 100.

${ }^{270}$ Malani \& Posner, supra note 27, at 2018-19; cf. Eldar, supra note 10, at 97 (discussing the proliferation of hybrid organizations and arguing against the notion that such organizations should receive tax benefits and subsidies akin to nonprofits); Brian Galle, Keep Charity Charitable, 88 Tex. L. Rev. 1213, 1213-15 (2010) (arguing that the federal government should continue to grant tax deductions only to true nonprofits); James R. Hines, Jr. et al., The Attack on Nonprofit Status: A Charitable Assessment, 108 Mich. L. Rev. 1179, 1180-84 (2010) (arguing that the tax avoidance costs associated with for-profit charities outweigh potential benefits).

${ }^{271}$ Mary Reynolds Babcock Found., Community Development Financial Institutions: A Study on Growth and Sustainability 26 (2011), https://www.cdfifund.gov/Documents/(64)\%20CDFIs\%20A\%20Study\%20on\%20Growth\%20and\%20Sustainability.p df [https://perma.cc/J7CK-7VPY].

272 PRI Makers Network, supra note 210, at 1-2.
} 
As discussed above, the main obstacle to streamlining PRIs is the lack of clear criteria with respect to eligible investees. The solution may be to treat investments in certified social enterprises as qualifying automatically as PRIs; the rationale is that such subsidized investments have a clear development mission and there is a high likelihood that they will be used efficiently towards that mission. This type of modest government subsidy could unlock significant foundation funding for social enterprises.

To the extent that investment by foundations is not sufficient, it may be desirable to introduce corporate subsidies, similar to those offered by the CDFI Fund. The federal agency responsible for certifying social enterprises could be responsible for allocating such subsidies. ${ }^{273}$

The main risk with such corporate subsidies is that they might be excessive. In principle, the subsidies should cover two components: (i) the costs of measuring or gathering information on beneficiaries' abilities (including any fixed start-up costs) $)^{274}$ and (ii) the cost of directly allocating subsidies to them. Any amounts in excess of these costs are not necessary to induce the corporation to transact with the beneficiaries. While some excess subsidies may be harmless, overly excessive subsidies may eliminate the firm's incentives to tailor subsidies to the needs of its beneficiaries and utilize subsidies effectively.

If a social enterprise receives excessive subsidies, its financial viability may no longer depend on the performance of its beneficiaries, but rather on continued subsidies. If the excess subsidy flows to the owners, they may lose the motivation to maximize profits. The reason is that if owners both maximize profits and receive large subsidies, they can distribute large surpluses to themselves. The subsidy providers may observe the surpluses, realize that the subsidy is excessive, and cut it off. It may therefore be more advantageous for owners to simply distribute some of the subsidies to themselves for personal gain and exert fewer efforts in maximizing profits. As a result, the managers will also have fewer incentives to measure beneficiaries' abilities, and hence their development will falter.

${ }^{273}$ Entrusting the allocation of such subsidies to a specialized regulator is consistent with the theory that a spending program should be assigned to the government unit with the greatest expertise in that area. See David A. Weisbach \& Jacob Nussim, The Integration of Tax and Spending Programs, 113 Yale L.J. 955, 1027-28 (2004).

${ }^{274}$ These costs equal the difference between the costs of measuring the abilities of those that do not belong to a disadvantaged group and those that do belong to such a group. 
The risk of excessive government subsidies is particularly acute because governments may have political reasons to provide corporations with large subsidies - either to benefit the corporations themselves, or to signal their own commitment to development issues. A textbook example is the India Rural Development Program, a grand-scale subsidy program whereby the Indian government subsidized banks that made loans to lowincome borrowers in accordance with certain arbitrary lending targets. ${ }^{275}$ The government continued to recapitalize banks that suffered extreme defaults, amounting effectively to direct allocation of subsidies. Knowing that the government would bail them out, these banks had limited incentives to measure their borrowers' creditworthiness.

This risk is less pronounced for private subsidies from investors and consumers, primarily because the subsidies tend to be smaller and large altruistic investors (such as foundations) typically maintain control over the firm to ensure that subsidies are not excessive. To the extent that the social enterprise law promotes the proliferation of social enterprises, these firms would effectively compete for subsidies from investors and consumers. That is likely to drive down excessive subsidies such that there will ultimately be very few.

Moreover, a government program may be designed to curb excessive subsidies. Again, the CDFI program may be a model approach, as it incorporates safeguards against the risk that subsidies will be wasted. First, the CDFI Fund may not provide more than $\$ 5$ million of assistance during any three-year period to any one CDFI or its subsidiaries and affiliates. ${ }^{276}$ Second, subject to exceptional circumstances, each CDFI is required to match its financial award dollar-for-dollar with non-federal funds. ${ }^{277}$ In fact, even technical assistance is not necessarily free, and the CDFI Fund may collect a regulatory fee to cover its costs of assistance. ${ }^{278}$ Third, the allocation of awards is conducted in a competitive process following publication of a "notice of fund availability," which specifies the amount of available subsidies and additional conditions the CDFI

\footnotetext{
275 Beatriz Armendáriz \& Jonathan Morduch, The Economics of Microfinance 10-11 (2d ed. 2010).

27612 U.S.C. $\$ 4707(d)(1)$ (2018); 12 C.F.R. § 1805.402(a) (2019). An affiliate or subsidiary of that CDFI may be eligible for additional assistance of up to $\$ 3.75$ million during the same three-year period if it serves a distinct investment area or targeted population. 12 U.S.C. $\S 4707(d)(2)$ (2018); 12 C.F.R. $§ 1805.402(b)$ (2019).

27712 U.S.C. $\$ 4707(\mathrm{e})(1)(2018)$.

278 Id. § 4708(f)(1).
} 
Fund deems appropriate. ${ }^{279}$ Applicants for assistance are evaluated on a merit basis that takes into account a wide range of factors, including their ability to meet their business objectives, the experience of the management team, the likely success of raising matching funds, the extent to which they will focus their activities to serve their beneficiaries, and CDFIs' past success (if any) in meeting performance goals. ${ }^{280}$ This means that the CDFI Fund chooses CDFIs that it deems to have the highest social impact.

Similarly, the allocation of tax credits under the NMTC program is conducted in a competitive process, where the CDFI Fund considers both the applicant's financial strength and its commitment to serving lowincome communities. ${ }^{281}$ In addition, by definition, tax credits are based on matched funding. As mentioned above, they amount to thirty-nine percent of the original investment amount and are claimed over a period of seven years. ${ }^{282}$

Should investors get tax credits for investments in social enterprises? To the extent that social enterprises still need additional capital despite the proposed law, tax credits may be desirable on similar grounds as donations to donative organizations. ${ }^{283}$ It is possible that investors may withhold subsidized investment in firms whose purposes they favor because they prefer to free-ride on other investors. Such free-riding may dissuade other investors from investing. Tax credits may encourage generosity by mitigating free-riding. They can also help in identifying popular preferences because the firms are chosen by investors that claim the tax credits, presumably on the basis of the identity of the beneficiaries they wish to support. Furthermore, tax credits recruit private monitors, such as social impact investors, that likely have the resources and incentives to evaluate the businesses and management of social enterprises. $^{284}$

\footnotetext{
27984 Fed. Reg. 30,802 VI(C)(2) (June 27, 2019).

28012 C.F.R. $\$ \S 1805.700,1805.701$ (2019).

${ }^{281}$ See supra note 199.

282 Id.

${ }^{283}$ David M. Schizer, Subsidizing Charitable Contributions: Incentives, Information, and the Private Pursuit of Public Goals, 62 N.Y.U. Tax L. Rev. 221, 239 (2009).

${ }^{284}$ Tax credits may be unnecessary, though, to induce consumers and small investors to provide subsidies because the subsidies they provide tend to be limited in amount. Id. at 237 .
} 


\section{CONCLUSION}

Encouraging firms to pursue social goals has been a policy objective for nearly as long as business enterprise forms have existed. The key to addressing this objective is to recognize that firms that pursue social missions are essentially conduits for subsidies to different classes of beneficiaries. A legal form is needed to assure subsidy-providersprimarily investors and consumers - that the firm will use these subsidies effectively. Thus, the design of such a form must be such that those who control it have both the incentives and the competence to use the subsidies effectively. The standard corporate form and most of the existing legal hybrid forms are simply not well designed for this purpose.

This is not, however, a pessimistic conclusion; instead, I argue for the enactment of a new social enterprise legal form that commits the firms that adopt it to transacting with different types of disadvantaged groups. The form would introduce a federal social enterprise certification mechanism, and would require firms wishing to form as social enterprises to obtain that certification. This certification would provide a credible commitment to altruistic consumers and investors that the social enterprise transacts with a class of disadvantaged individuals. This proposal has the potential to unlock vast altruistic capital and incomefrom ethical consumers, socially responsible funds, altruistic investors, and, most importantly, foundations.

Such a dual regulatory regime that combines federal supervision with state corporate laws is not as unusual as it may seem. In fact, the nonprofit form is already regulated by the IRS as well as by state corporation laws. Similarly, the social enterprise regulator would certify firms as being eligible for subsidies, and each state's social enterprise statute would govern shareholders' ability to convert to and from a social enterprise. Accordingly, the proposed system is consistent with, and complementary to, the current system of nonprofit laws.

Finally, the analysis in this Article also articulates the functional resemblance between government subsidy programs - such as the CDFI program-and legal forms for firms that pursue social missions. Ultimately, both legal mechanisms share the goal of creating a credible commitment to subsidy-providers, whether the government or private parties. The social enterprise legal form, if adopted, could subsume existing government programs to promote development. ${ }^{285}$ In this respect,

285 See supra Section III.B. 
the proposal could also help in resolving the design flaws in government subsidy programs that have had disappointing results. 